\title{
Jute Based Bio and Hybrid Composites and Their Applications
}

\author{
Muhammad Ahsan Ashraf ${ }^{1}$, Mohammed Zwawi ${ }^{2}$, Muhammad Taqi Mehran ${ }^{1}$, \\ Ramesh Kanthasamy ${ }^{3}$ and Ali Bahadar ${ }^{3, * \mathbb{D}}$ \\ 1 School of Chemical and Materials Engineering (SCME), National University of Sciences and \\ Technology (NUST), Islamabad 44000, Pakistan \\ 2 Department of Mechanical Engineering, King Abdulaziz University, Rabigh 21911, Saudi Arabia \\ 3 Department of Chemical and Materials Engineering, King Abdulaziz University, Rabigh 21911, Saudi Arabia \\ * Correspondence: absali@kau.edu.sa or engrbahadur@gmail.com
}

Received: 19 June 2019; Accepted: 22 August 2019; Published: 28 August 2019

check for updates

\begin{abstract}
The popularity of jute-based bio and hybrid composites is mainly due to an increase in environmental concerns and pollution. Jute fibers have low cost, high abundance, and reasonable mechanical properties. Research in all-natural fibers and composites have increased exponentially due to the environment concerns of the hazards of synthetic fibers-based composites. Jute based bio and hybrid composites have been extensively used in number of applications. Hybrid jute-based composites have enhanced mechanical and physical properties, reasonably better than jute fiber composites. A detailed analysis of jute-based bio and hybrid composites was carried out in this review. The primary aim of this review paper is to provide a critical analysis and to discuss all recent developments in jute-based composites. The content covers different aspects of jute-based composites, including their mechanical and physical properties, structure, morphology, chemical composition, fiber modification techniques, surface treatments, jute based hybrid composites, limitations, and applications. Jute-based composites are currently being used in a vast number of applications such as in textiles, construction, cosmetics, medical, packaging, automobile, and furniture industries.
\end{abstract}

Keywords: hybrid bio-composite; natural fiber; extrusion; jute; renewable

\section{Introduction}

We are surrounded by environmental pollution, which has now become a major threat to all living creatures. Leading nations are trying to minimize pollution by taking radical steps to replace pollution-causing materials with renewable ones. Researchers have made it possible to replace conventional synthetic materials with natural bio-based alternatives. Composite materials are considered to be one of the most important materials in diversified and load-bearing applications. Many resources have been spent on developing synthetic composites, which have performed well in different applications. But now, with ever-increasing environmental concerns and threats, much focus has been diverted to the development of bio- and hybrid composites. As a result, in the past few years, a great deal of attention has been paid to the development of these composites. Currently, bio-composites are being developed to meet the performance of synthetic composites. These bio-composites are biodegradable and various natural fibers have been used for their fabrication, aiming at making them eco-friendly in nature and with minimum carbon emissions. Even hybrid composites have also become popular due to superior mechanical and physical properties compared to pure bio-composites. Bio-composites are natural, light in weight, low in carbon emissions, and low in material and manufacturing costs. And above all, these fibers used in the manufacturing of bio-composites are abundant in nature. Bio-composites are on the verge of becoming an integral part of society due to their 
various useful applications [1]. Consequently, bio-composites have emerged as the best replacement for synthetic composites. Different bio-composites are at various developmental stages, both in research and in the industrial community. Many bio-composite materials have shown mechanical and physical properties comparable to that of synthetic composites. These natural fibers are adequate replacements for glass and carbon fibers. Despite swift progress in this field, many shortcomings and limitations still exist, hindering the practical implementation of these natural fibers. The limitations of bio-based polymers and composites include poor adhesion between polymer and matrix, incompatibility of fibers, agglomeration of fibers, and a lack of manufacturing processes [2,3]. Research is being carried out in developed and developing countries with the aim of overcoming the outstanding issues related to bio-composites. Many countries are taking further steps ahead by encouraging industries to use bio-composites and also by giving them different trading incentives, while industries themselves are adopting these bio-composites for various international certifications and for gaining access to international markets. Biodegradable materials will not only benefit us environmentally but will also help to improve economic outlooks [4].

Recently, bio-composites and bio-degradable materials have gained much momentum. These materials are subjected to continuous research development regarding numerous industrial sectors. Different plant fibers are shown in Figure 1 [5-8]. Among various different natural fibers, jute is one of the most important fibers used in the manufacturing of bio-composites. Jute belongs to the bast fiber family and is normally grown in the tropical areas of China, Bangladesh, India, and Indonesia. It is considered to be one of the most produced fibers in the world [9]. Jute can easily be grown in a humid atmosphere and warm temperature range. Additionally, jute is known as a rainy season crop and can survive flood conditions. Jute is solely grown for the extraction of fibers [6]. Jute plants are differentiated based on plant type, color, strength, and length of fibers. White and Tossa jute are the two main types of jute plants [10] which are cultivated in tropical and high-temperature areas. Asia is the biggest producer of jute and contributes to around $95 \%$ of total jute production in the world [6]. Jute fibers have gained much attention in the last few years due to their physical and mechanical properties. The mechanical properties of jute fibers are believed to be comparable to glass fiber in terms of specific strength and specific modulus [11].

In addition, jute fibers are eco-friendly, renewable, cheap to produce, and bio-degradable [12]. The main constituents of jute fibers are cellulose and lignin. Cellulose is a polysaccharide that helps to form hydrogen bonding between matrix and natural-fiber-improving interfacial adhesions [13]. Jute fiber has a high demand from textiles other than the composite and bio-polymer industries [14]. The properties of jute fibers are usually determined by the maturity of the plant, fiber length, and the processing techniques used for the manufacturing of composites [6]. Jute fiber is currently being used in many applications including textiles, automobiles, and even in some load-bearing applications. In the automobile sector, bio-composites and bio-polymers of jute are used to produce different components such as door panels, trunk liners, and cup holders [15,16]. Even big auto manufacturers such as Mercedes, along with many European and American car manufacturers, are keen to use more renewable composites and polymers [17]. The annual production of various natural fibers is shown in Table 1 [6,18-20].

Over the last few years, jute-based hybrid composites containing natural components have emerged with better mechanical properties than natural jute-based composites. Usually hybrid composites are made from a combination of natural and synthetic fibers in a matrix while bio-composites consist of natural fibers and synthetic or natural material composite. Hybrid composites contain less percentage of natural fibers but the shortcomings of all-natural fiber composites can be overcome by reducing natural fiber content with the addition of synthetic fibers such as glass fibers. 
Table 1. Annual production of different fibers.

\begin{tabular}{ccc}
\hline Fiber Source & Fiber Type & Annual Production (10 $\mathbf{3}^{\mathbf{3}}$ Tonnes) \\
\hline Jute & Bast and Core fiber & 3600 \\
Bamboo & Wood fiber & 30,000 \\
Sugar cane & Wood or Stem fiber & 75,000 \\
Grass & Grass fiber & $700-750$ \\
Ramie & Bast fiber & $100-110$ \\
Abaca & Leaf fiber & $70-90$ \\
Hemp & Bast and Core fiber & $200-220$ \\
Sisal & Leaf fiber & $370-380$ \\
Coir & Seed fiber & $600-650$ \\
Kenaf & Bast and Core fiber & $950-990$ \\
Flax & Bast fiber & 830 \\
\hline
\end{tabular}

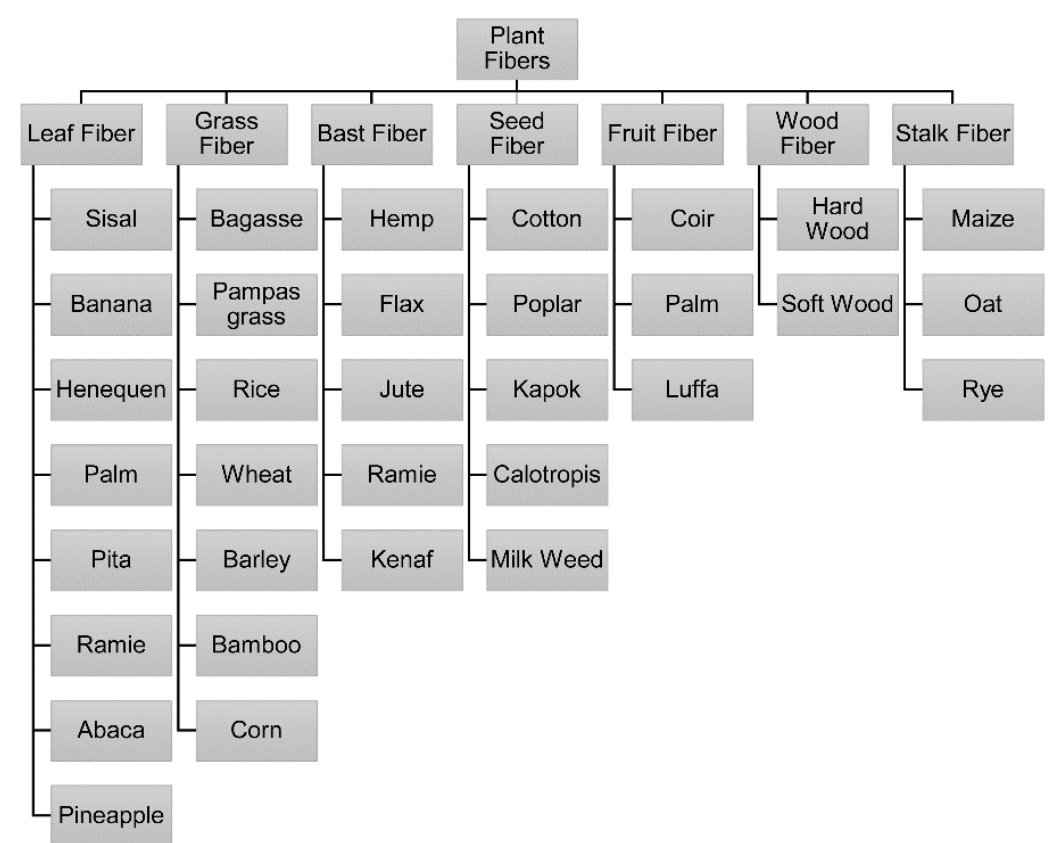

Figure 1. Different types of plant fibers.

In this review, we aim to discuss recent developments regarding jute-based bio and hybrid composites. The main objective of this review is to provide a critical assessment of the literature and to summarize the key findings of different jute-based research studies. This review paper contains the mechanical and physical properties, structure, morphology and chemical composition, fiber-modification techniques, surface treatments, limitations and applications of jute fiber-based bio- and hybrid composites. The present work also focuses on methods to improve properties by overcoming the limitations associated with these jute-based composites. Due to huge number of potential applications, jute-based composites have become a topic of interest in the research community. The applications of these composites include textiles, automobiles, polymers, medical, cosmetic, and construction industries.

\section{Structure, Morphology, and Chemical Composition of Jute}

Jute fibers, obtained from jute plants, are commonly known as lignocellulosic fibers [21]. Jute fibers are multi-cellular and can be found in the bast region of jute plants, stretching along the stem [22,23]. A single jute fiber is formed by combining different cells and constituents like lignin, cellulose, oils, waxes, and the different types of fats [24]. These cementing constituents help in the formation of a network of jute fibers in the stem region and this network of jute fibers is called a strand. Jute fibers 
join with one another to form long fibers and a meshy network [25]. The geometry and composition of jute fibers can vary from plant to plant due to differences in growth conditions. The composition can even vary from fiber to fiber in a single plant [25]. Jute fiber structure, length, and chemical composition are dependent on factors like growth environment, weather conditions, defects, plant maturity, extraction, and the modification methods used [2]. Lumen is a central hollow cavity present in a jute fiber cell, which produces fiber with a low density [26,27]. Each unit cell of fiber is connected with other cells through the middle lamella, which is usually composed of lignin and cellulose. This middle lamella is responsible for joining different unit cells [28].

Jute fiber is composed of different types of polysaccharides and lignin. Polysaccharides are made up of hemicellulose and alpha cellulose [29]. In jute fiber, cellulose is the primary constituent of the cell wall and consists of different glucose rings. Glucose rings form cellobiose consisting of repeating units of glucose dimers [30]. Linear polymerization of glucose rings forms a cell wall and ultimately the jute fiber. These glucose rings interact with one another through covalent bonds that are responsible for different physical and mechanical properties [31]. Hydroxyl groups present in this glucose and the cellulose chain interacts with other hydroxyl groups and water molecules, forming hydrogen bonds. Hydrogen bonds between these hydroxyl groups are also responsible for the hydrophilic nature, crystallization, and three-dimensional structure of jute fiber. Cellulose has a hydrophilic nature and is dissolvable in water. Due to these factors, water is absorbed in cellulose, which can cause an overall swelling of the fiber [32,33]. Jute fiber is acidic in nature due to the presence of hemicellulose and poly-uronic acid [34]. The close and microscopic examination of unit cells revealed that crystallization is not homogenous throughout the fiber. Highly-ordered and closely-packed regions are known as micro-fibril structures, while loosely packed and non-homogenous regions are usually called fringed fibril areas. Highly-ordered regions are crystalline while non-homogenous regions are amorphous. A micro-fibril angle with respect to plant length is also responsible for different mechanical and physical properties [35]. Cellulose can be divided into cellulose I alpha, cellulose I beta, cellulose II, and cellulose III. The cell wall consists of a primary and secondary cell wall. The primary cell wall is usually thin while the secondary cell wall is usually a thick layer, though both are formed by a combination of very fine micro-fibrils [36]. The primary cell wall has a crisscross-linking of micro-fibrils while the secondary cell wall has highly-ordered micro-fibril arrangements [37,38]. Microfibrils have nano-crystals of cellulose I alpha.

Figure 2 shows the cross-section of the jute fiber.

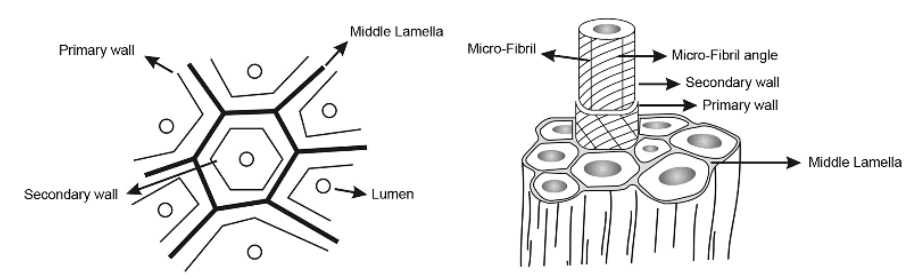

Figure 2. Showing cross section of jute fiber. Reproduced with permission from Roy and Lutfar [39].

Jute fiber is mainly composed of lignin, cellulose, waxes, pectin, protein, nitrogenous compounds, and mineral and inorganic matter. Cellulose is further divided into alpha cellulose and hemicellulose, with these constituents varying slightly from plant to plant and in different growing conditions. Cellulose is the main constituent of jute fiber. Normally, a jute fiber contains around 59-63\% of alpha cellulose, $22-26 \%$ of hemicellulose, $12-14 \%$ lignin, $0.4-0.8 \%$ of waxes, $0.2-0.5 \%$ of pectin, $0.6-1.2 \%$ of mineral matter and traces of other constituents $[18,40,41]$. Glucose is a basic building unit of cellulose, which cannot be easily oxidized though acids can hydrolyze the substance. Alpha cellulose consists of long cellulose chains with a combination of high molecular weight polysaccharides [4], while hemicellulose is formed by the combination of a small-length cellulose chain with low molecular weight polysaccharides. Hemicellulose has a branched structure, giving rise to an amorphous nature. Hemicellulose is believed to act as a binder between different constituents in jute fiber, such as 
micro-fibrils and lignin, while pectin gives plant structure its elasticity. Jute fiber also contains some minor traces of waxes, which are insoluble in water and acids [14,42,43].

Lignin is known to be one of the most abundant polymers [44], which is considered to be a complex three-dimensional structure with a presence of aliphatic and aromatic groups. Lignin consists of a high amount of carbon along with a low amount of hydrogen [45]. These amounts of carbon and hydrogen make lignin aromatic or unsaturated in nature with the presence of hydroxyl, carboxyl, and methoxyl groups. The basic unit cell of lignin is composed of hydroxyl and methoxyl groups, which make the constituent complex and amorphous. It is readily soluble in alkali and can be oxidized and condensed, though it cannot be hydrolyzed by an acidic medium [4]. Lignin is connected with other constituents of jute fiber through being alkali resistant and having alkali-sensitive links. Alkali-sensitive linkage is in-between the hydroxyl groups of lignin and the carboxyl groups of cellulose or hemicellulose, while the alkali-resistant link is actually a crosslinking of the hydroxyl groups of lignin and cellulosic constituents [46]. Lignin usually provides support to plants and has a hydrophobic nature.

\section{Mechanical Properties of Jute Fiber}

Jute fiber is considered to be one of the most important fibers for the production of bio-composites and bio-plastics. Much research can be found studying the different mechanical properties of jute fiber, which have acceptable mechanical properties like tensile properties, specific strength, and modulus, hence increasing its potential use in different applications [47]. The values of the different mechanical properties of jute fiber reported by researchers are listed below in Table 2. The addition of synthetic fibers in jute-based composites are found to increase its mechanical properties. These hybrid composites have shown better results and mechanical properties than that of bio-composites made up of jute fiber [36]. Hybrid composites are the combination of two or more natural and synthetic fibers with matrix material [48]. Synthetic fiber helps to balance the shortcomings associated with natural fibers [49] and helps to increase the mechanical properties and to decrease costs associated with composites $[4,26]$. Mechanical properties are dependent on many factors, one of the most important factors is the fiber length of composite [50]. The critical length of fiber is important to have better mechanical properties, stress transfer, and good fiber/matrix. Fiber length is critical for carrying maximum load. Fiber length beyond critical length results in poor fiber/matrix adhesion and poor stress transfer which will result in failure and the pre-mature fracture of fibers [51]. Chollakup et al. [52] studied the effects of long and short fibers of pineapple leaf on properties of composites. Composites with longer fiber length were found to be stronger in comparison with short fibers. Longer fibers exhibited homogenous dispersion while short fibers were heterogeneously dispersed. The tip or end of short fibers behaves as a stress concentrating site, leading to poor stress and load transfer from matrix to fibers. Controlling fiber orientation and aggregation are some of the issues associated with short fibers [53]. Mishra et al. [54] studied a hybrid composite of jute with epoxy and found an increase in flexural, tensile, and impact strength. The composite was found to have better mechanical interlocking between fiber and matrix. Abdullah Al et al. [55] studied the mechanical properties of jute fiber with epoxy glass fiber. They found that the mechanical properties were improved with the addition of glass fiber. An ultraviolet radiation technique was used to further improve the mechanical properties of the jute/glass fiber composite. Ahmed and Vijayarangan [56] studied the different mechanical properties of the jute/glass fiber composite. Significant improvements were observed in mechanical properties with the addition of glass fiber. Ahmed et al. [57] studied the effects of glass fiber when added to jute fiber to form a hybrid composite. In this research, it was presented that mechanical properties like tensile, interlaminar shear, and flexural strength showed notable improvement with the addition of glass fiber. The addition of just $16.5 \mathrm{wt} \%$ of glass fiber improved the shear, tensile, and flexural strength properties by $17.6 \%$, $37 \%$, and $31.23 \%$, respectively. This hybrid composite showed a better resistance to moisture. As jute fiber is hydrophilic in nature, which is a major hindrance to achieving better mechanical properties. The low mechanical properties of jute fiber are due to poor fiber-matrix adhesion, fire resistance, and thermal degradation [58]. Zamri et al. [59] studied the effects of water absorption on the mechanical 
properties of a jute/glass fiber composite. Mechanical properties like flexural and compression strengths were significantly declined after water absorption. Many surface treatment methods are reported in literature to improve the mechanical properties of jute fibers. Table 3 depicts the mechanical properties and surface treatments of jute-based composites. These methods include physical, chemical and physio-chemical, and mechanical surface modification methods. These methods are found to be effective in improving the mechanical properties of fibers [2]. Figure 3 shows a comparison of tensile strength of treated and untreated jute fiber composites. A jute/polylactide [60] composite was fabricated using $50 \mathrm{wt} \%$ jute fiber and treated with $5 \%$ aqueous $\mathrm{NaOH}$ solution. Alkali treatment increased roughness which improved fiber/matrix adhesion. A jute/polypropylene [61] composite was fabricated using $25 \mathrm{wt} \%$ jute and was post-treated with urea. Tensile strength increased significantly after the urea post treatment. Jute/epoxy [62] was fabricated by the hand lay-up technique and treated with $20 \% \mathrm{NaOH}$. A jute/polypropylene composite was fabricated using a hand-lay-up technique. Jute fibers were treated with $7 \% \mathrm{NaOH}$.

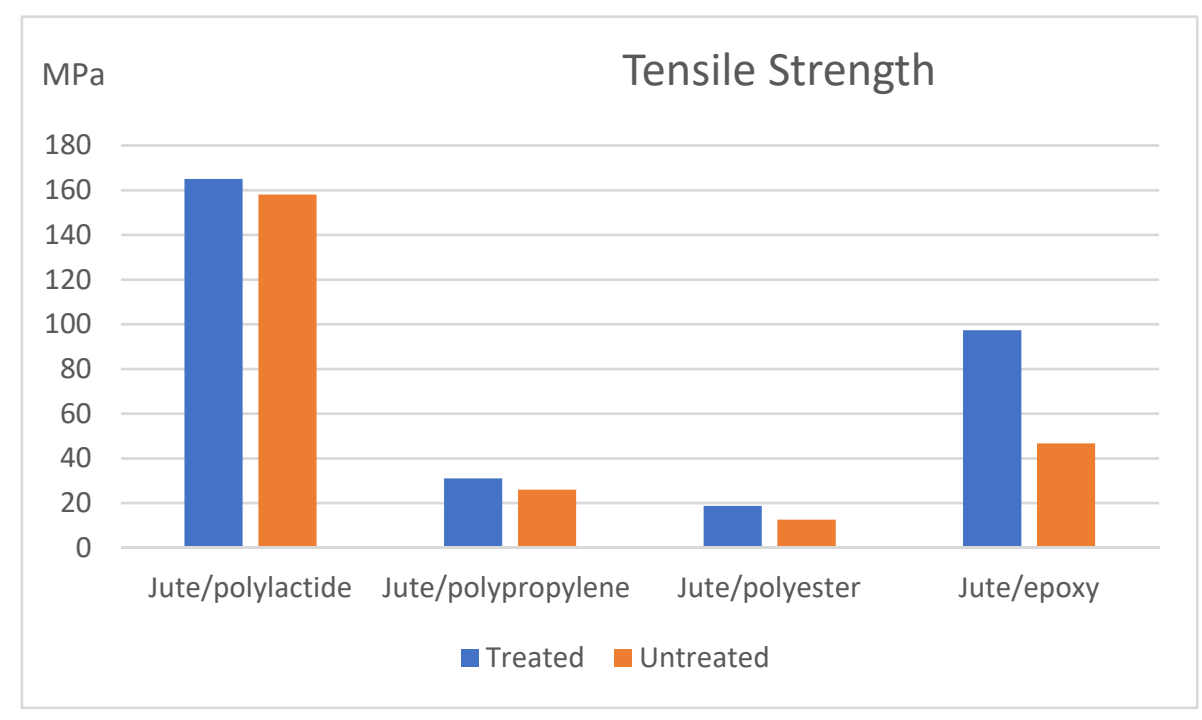

Figure 3. Showing tensile strength comparison of treated and untreated jute composite.

Table 2. Mechanical properties of jute fiber.

\begin{tabular}{|c|c|c|c|c|c|c|c|c|c|}
\hline \multicolumn{10}{|c|}{ Mechanical Properties of Jute Fiber } \\
\hline $\begin{array}{l}\text { Density } \\
\left(\mathrm{g} / \mathrm{cm}^{3}\right)\end{array}$ & $\begin{array}{l}\text { Diameter } \\
(\mu \mathrm{m})\end{array}$ & $\begin{array}{c}\text { Micro-Fibrillar } \\
\text { Angle }\left({ }^{\circ}\right)\end{array}$ & $\begin{array}{c}\text { Moisture } \\
\text { Content (\%) }\end{array}$ & $\begin{array}{c}\text { Tensile } \\
\text { Strength } \\
\text { (MPa) }\end{array}$ & $\begin{array}{c}\text { Tensile } \\
\text { Modulus } \\
\text { (GPa) }\end{array}$ & $\begin{array}{c}\text { Specific } \\
\text { Strength } \\
\left(\mathrm{MPa} / \mathrm{g} \cdot \mathrm{m}^{-3}\right) \\
(\mathrm{S} / \rho)\end{array}$ & $\begin{array}{c}\text { Specific } \\
\text { Modulus } \\
\left(\mathrm{GPa} / \mathrm{g} \cdot \mathrm{m}^{-3}\right) \\
(\mathrm{E} / \rho)\end{array}$ & $\begin{array}{c}\text { Elongation at } \\
\text { Break }(\%)\end{array}$ & References \\
\hline $1.3-1.5$ & - & - & - & $200-770$ & $20-55$ & $310-625$ & $2-37$ & - & {$[33,63-66]$} \\
\hline $1.3-1.45$ & - & - & - & $393-780$ & $13-30$ & - & - & 1.9 & {$[67,68]$} \\
\hline $1.3-1.45$ & $20-200$ & - & - & $393-773$ & $13-26.5$ & - & - & $7-8$ & [69] \\
\hline- & $25-30$ & $7-9$ & - & $393-800$ & $13-27$ & - & - & 0.7 & {$[71,72]$} \\
\hline $1.3-1.5$ & - & 8 & - & $393-800$ & $13-26.5$ & - & - & $1.2-1.8$ & [73] \\
\hline $1.3-1.49$ & $20-200$ & 8 & $15.5-13.7$ & $320-800$ & $8-78$ & - & 30 & $1-1.8$ & [74] \\
\hline 1.23 & $5-25$ & - & 12 & $187-773$ & $20-55$ & $140-320$ & $14-39$ & $1.5-3.1$ & {$[2,46,75,76]$} \\
\hline $1.3-1.5$ & - & - & 12 & $393-800$ & $10-55$ & $300-610$ & 7.1-39 & $1.5-1.8$ & {$[33,77,78]$} \\
\hline
\end{tabular}


Table 3. Mechanical properties and surface treatments of different jute-based composites.

\begin{tabular}{|c|c|c|c|c|c|}
\hline Jute Composite & Fabrication Method & Key Parameters and Findings & Mechanical Properties & $\begin{array}{l}\text { Surface Treatments and Effects on Mechanical } \\
\text { Properties }\end{array}$ & References \\
\hline Jute/epoxy & Hand lay-up & $\begin{array}{l}\text { Void content decreased and } \\
\text { mechanical properties increased with } \\
\text { the increase in jute fiber content } \\
\text { in composite. }\end{array}$ & $\begin{array}{l}\text { Properties like hardness, impact strength and tensile } \\
\text { strength increased with the increase in jute fiber } \\
\text { content due to improved fiber/matrix adhesion with } \\
\text { better interlocking. Inclusion of fibers increases } \\
\text { modulus of composite, increasing overall hardness. }\end{array}$ & - & [47] \\
\hline $\begin{array}{l}\text { Glass/jute fiber } \\
\text { reinforced epoxy } \\
\text { composite }\end{array}$ & Hand lay-up & $\begin{array}{l}\text { Flexural load separated fibers from } \\
\text { matrix upon failure. }\end{array}$ & $\begin{array}{l}\text { Jute-glass fiber composite had tensile strength up to } \\
63 \mathrm{MPa} \text { and flexural load up to } 1.03 \mathrm{KN} \text {. }\end{array}$ & - & [68] \\
\hline $\begin{array}{l}\text { Jute fiber reinforced } \\
\text { with epoxy and } \\
\text { polyester matrices }\end{array}$ & Compression molding & $\begin{array}{l}20 \mathrm{wt} \% \text { jute fibers and } 80 \mathrm{wt} \% \text { matrix } \\
\text { materials were used with fiber length } \\
\text { of } 2-3 \mathrm{~mm} \text {. }\end{array}$ & $\begin{array}{l}\text { Jute epoxy composite had higher tensile strength, } \\
\text { flexural strength and tensile modulus due to better } \\
\text { stress distribution and fiber/matrix adhesion. }\end{array}$ & $\begin{array}{l}5 \% \mathrm{NaOH} \text { (alkali treated) jute fiber composites } \\
\text { showed better tensile strengths and flexural } \\
\text { strengths than } 10 \% \mathrm{NaOH} \text { treated composites. }\end{array}$ & [36] \\
\hline $\begin{array}{l}\text { Jute/glass fiber } \\
\text { reinforced epoxy } \\
\text { composite }\end{array}$ & Hand lay-up & $\begin{array}{l}64-69 \% \text { of epoxy resin, } 18-31 \% \text { of jute } \\
\text { fibers, } 0-19 \% \text { of glass fibers were used } \\
\text { in fabrication of different samples. }\end{array}$ & $\begin{array}{l}\text { Increase in glass fiber content increased mechanical } \\
\text { properties of composite. } \\
\text { Composite with } 64 \% \text { epoxy resin, } 18 \% \text { of jute fibers } \\
\text { and } 19 \% \text { of glass fiber had better tensile strength } \\
\text { while flexural strength had not any significant } \\
\text { change. Greater jute content led to rapid mass loss } \\
\text { and increased moisture absorption. }\end{array}$ & - & [79] \\
\hline $\begin{array}{l}\text { Polylactide and jute } \\
\text { composite }\end{array}$ & Solvent casting method & $\begin{array}{l}\text { Samples with } 50 \mathrm{wt} \% \text { of jute } \\
\text { were fabricated. }\end{array}$ & $\begin{array}{l}\text { Tensile strength, tensile modulus, Izod impact } \\
\text { strength, flexural strength and modulus for } \\
\text { untreated jute/polylactide were } 158 \mathrm{MPa}, 5.3 \mathrm{GPa}, \\
60 \mathrm{KJ} / \mathrm{m}^{2}, 180 \mathrm{MPa} \text { and } 10.5 \mathrm{GPa} \text { respectively. } \\
\text { Untreated samples had greater Izod impact strength } \\
\text { and thermal stabilitity due to fiber pull out } \\
\text { mechanism. While treated samples had fractured } \\
\text { fibers which require less energy than pull } \\
\text { out mechanism. }\end{array}$ & $\begin{array}{l}\text { Samples were modified by alkali, silane, peroxide } \\
\text { and permanganate surface treatments. } \\
\text { Silane treated samples had elevated values for } \\
\text { tensile strength and modulus, flexural strength } \\
\text { and modulus. Surface treatments increase surface } \\
\text { roughness which in turn increases fiber/matrix } \\
\text { adhesion and inter-locking. Surface treatment } \\
\text { alters fiber structure and can chemically modify } \\
\text { mechanical properties, increasing mechanical } \\
\text { properties of composite. }\end{array}$ & [60] \\
\hline $\begin{array}{l}\text { Jute fiber/polypropylene } \\
\text { composite }\end{array}$ & Extrusion & $\begin{array}{l}30 \mathrm{wt} \% \text { of fiber loading had optimum } \\
\text { mechanical properties. }\end{array}$ & $\begin{array}{l}\text { Tensile strength showed decreasing trend as increase } \\
\text { in jute fiber content increased the area of fiber/matrix } \\
\text { interface, while tensile modulus increased due to } \\
\text { obstruction in stress propagation by micro spaces. } \\
\text { Flexural strength and modulus increased up to } 30 \mathrm{wt} \\
\% \text { fiber loading. Impact strength showed an } \\
\text { increasing trend as larger force is required to pull } \\
\text { out fibers up till } 30 \mathrm{wt} \% \text { of jute contents. }\end{array}$ & $\begin{array}{l}\text { Urea treatment improved properties such as } \\
\text { fiber/matrix adhesion, tensile strength and } \\
\text { modulus, flexural strength and modulus and } \\
\text { impact strength }\end{array}$ & [61] \\
\hline
\end{tabular}


Table 3. Cont

\begin{tabular}{|c|c|c|c|c|c|}
\hline Jute Composite & Fabrication Method & Key Parameters and Findings & Mechanical Properties & $\begin{array}{c}\text { Surface Treatments and Effects on Mechanical } \\
\text { Properties }\end{array}$ & References \\
\hline $\begin{array}{l}\text { Jute reinforced epoxy } \\
\text { composite }\end{array}$ & Hand lay-up & $\begin{array}{l}\text { Different mechanical and water } \\
\text { absorption properties were studied for } \\
\text { treated and untreated samples. }\end{array}$ & $\begin{array}{l}\text { Tensile strength and flexural strength of untreated } \\
\text { jute fiber epoxy composite were } 46.7 \text { and } \\
62.4 \mathrm{MPa} \text { respectively. }\end{array}$ & $\begin{array}{l}\text { Alkali treatment increased tensile strength by } 108 \% \\
\text { and flexural strength by } 28 \% \text {. }\end{array}$ & [62] \\
\hline $\begin{array}{l}\text { Jute/glass epoxy } \\
\text { composite }\end{array}$ & Hand lay-up & $\begin{array}{l}\text { Jute and glass fibers were used in } \\
\text { epoxy matrix to fabricate composite. }\end{array}$ & $\begin{array}{l}\text { Hardness values increased with the increase in glass } \\
\text { fiber content. Glass fibers have high hardness values } \\
\text { which increase hardness of composite. Tensile } \\
\text { strength showed increasing trend with the increase } \\
\text { in glass fiber composition. Natural fibers enhanced } \\
\text { degradability properties. and glass fibers } \\
\text { enhanced brittleness. }\end{array}$ & $\begin{array}{l}\text { Strength of composite increased by } 11 \% \text { when } \\
\text { fibers were treated with NaOH. Tensile strength for } \\
\text { treated composite increased due to removal of fiber } \\
\text { components such as hemicellulose, lignin along } \\
\text { with amorphous and crystalline parts of fibers. }\end{array}$ & [80] \\
\hline $\begin{array}{l}\text { Jute/Epoxy glass } \\
\text { composite }\end{array}$ & Hand lay-up & $\begin{array}{l}\text { Homogenous thickness of samples } \\
\text { was obtained through } \\
\text { compression technique. }\end{array}$ & $\begin{array}{l}\text { Jute/E-glass composite showed better tensile } \\
\text { strength than pure jute-based composite due to } \\
\text { better stress transfer. Jute fibers increased toughness } \\
\text { and decreased brittleness. While epoxy glass } \\
\text { improved erosion wear properties. }\end{array}$ & $\begin{array}{l}\text { Jute fibers were alkali treated to get rid of lignin, } \\
\text { hemicellulose, and cellulose from the surface } \\
\text { of fibers. }\end{array}$ & [81] \\
\hline $\begin{array}{l}\text { Jute/kenaf fibers } \\
\text { reinforced epoxy } \\
\text { composite }\end{array}$ & Hand lay-up & $\begin{array}{l}\text { Samples were prepared using } 56 \% \text { of } \\
\text { jute and kenaf fibers, } 40 \% \text { of epoxy, } \\
\text { and } 4 \% \text { of hardeners. }\end{array}$ & $\begin{array}{l}\text { Flexural strength, impact strength, tensile and } \\
\text { compressive strength of treated fibers had enhanced } \\
\text { values as compared untreated fibers composite. }\end{array}$ & $\begin{array}{l}\text { Surface treatment of kenaf and jute fibers removed } \\
\text { hemi-cellulose, pectin and other non-cellulosic } \\
\text { matter. Surface treatment increased surface area, } \\
\text { reduced moisture absorption and improved } \\
\text { roughness of fibers for better fiber/matrix adhesion. }\end{array}$ & [82] \\
\hline $\begin{array}{l}\text { Jute reinforced } \\
\text { polyester resin }\end{array}$ & Hand lay-up & $\begin{array}{l}\text { Composite samples were } \\
\text { manufactured through hand lay-up } \\
\text { techniques and were tested for } \\
\text { different mechanical properties. }\end{array}$ & $\begin{array}{l}\text { Values of tensile strength, elongation at break and } \\
\text { Young's modulus for untreated jute composite are } \\
12.61 \mathrm{MPa}, 20.96 \%, 84.63 \mathrm{MPa} \text {, respectively. }\end{array}$ & $\begin{array}{l}7 \% \mathrm{NaOH} \text { treated sample exhibited highest values } \\
\text { of tensile strength, elongation at break and Young's } \\
\text { modulus with increase of } 48.69 \%, 87.5 \% \text {, and } \\
62.94 \% \text { respectively from untreated sample. NaOH } \\
\text { treatment makes surface rough, improving } \\
\text { fiber/matrix adhesion which enhances } \\
\text { mechanical properties. }\end{array}$ & [83] \\
\hline
\end{tabular}




\section{Surface Treatments of Jute Fiber}

Many surface-modification techniques are used to improve physical, chemical, and mechanical properties. Surface modification techniques help in improving adhesion between fiber and matrix, reducing water absorption, and enhancing fire-resistance properties [84,85]. These modification techniques are roughly divided into two groups-chemical and physical surface modification techniques. It is noted that not all techniques are eco- and environmentally-friendly. Hence, before using any techniques, environmental hazards must be kept in mind. For some applications, these modification techniques may not be suitable, such as in the food packaging industry. Chemical surface-modification techniques involve acetylation treatment, silane, alkaline treatment, enzymic treatment, succinic, and maleic anhydride grafting. Whereas physical modification techniques involve ultraviolet radiations, gamma irradiation, electron beam irradiation, plasma and corona treatment $[86,87]$. Most chemical modification techniques are discussed in fiber modification techniques, while physical modification techniques will be discussed below. Table 3 shows various surface modification methods.

\section{Physical Modification Methods}

Physical modification techniques are widely employed to improve the different properties of jute fiber in order to compete with synthetic counterparts. Gamma radiation is the process of deposition of energy in cellulose, which is achieved through a process called Compton scattering. After energy deposition, macro-cellulosic radicals are produced through the localization of deposited energy. These cellulosic radicals are responsible for improving different mechanical and physical properties of jute fiber [88]. Many studies are available on the gamma radiation of jute fiber, which focuses on the improvement of jute through various gamma doses. Khan et al. [89] studied the effects of gamma radiation for jute fiber reinforced polypropylene composite on various mechanical properties, with gamma radiations doses between 250-1000 krad. Results depicted that pretreatment of jute fibers and polypropylene with $500 \mathrm{krad}$ of gamma radiation improved mechanical properties. Properties like tensile strength, impact strength, and bending strength improved by $27 \%, 73 \%$, and $27 \%$, respectively. Water intake for treated jute fiber composite was $6.97 \%$ as compared to $9.85 \%$ for untreated jute fiber composite. Gamma radiations can start scission and breaking of chemical bonds resulting in smaller polymeric molecules. The structure of matrix polymer is changed with the joining of these small molecules through cross-linking. Gamma radiations can increase active sites in matrix material. All these processes induced by radiations contribute in increasing mechanical properties of composite. Islam et al. [90] used gamma radiation for the surface modification of $50 \mathrm{wt} \%$ of treated jute, with $50-1000 \mathrm{krad}$ of gamma radiation. An increase of $45 \%$ in tensile modulus and a $5 \%$ increase in tensile strength were observed in this experiment. Gamma treatment improved bond strength by providing more active site for better fber/matrix adhesion and induced cross-linking in matrix material. The jute fiber composite showed the best mechanical properties at a dose of $500 \mathrm{krad}$.

The UV radiation technique is another method for improving the mechanical properties of jute fibers. UV radiation techniques also help in cross-linking between the polymeric matrix and fiber. Khan et al. [88] studied the effects of gamma radiations alongside the effects of pre-irradiated fibers with UV radiations prior to gamma radiations. Gamma radiations improved different mechanical properties. Of all jute composites used in the experiment, composites with $38 \%$ jute content showed better mechanical properties. Tensile strength was increased by $108 \%$, bending strength by $58 \%$, bending modulus by $211 \%$, and tensile modulus by $138 \%$, as compared to a pure polymeric film. Tensile and bending strength increased up to $500 \mathrm{krad}$ due to the formation of free radicals, increasing the degree of cross-linking. Tensile and bending strength decreased after $500 \mathrm{krad}$ of radiation, mainly due to degradation of cellulose backbone [91]. Similarly, samples pre-irradiated with ultraviolet radiation before gamma treatment exhibited even better properties. A $15 \%$ increase in bending strength and a 19\% increase in tensile strength were observed from the samples without UV treatment. There was a 150\% increase in tensile strength and a 90\% increase in bending strength in comparison with pure polymeric film. Abdullah-Al-Kafi et al. [55] studied the effects of UV radiation on jute/glass 
fiber composites where the $25 \mathrm{wt} \%$ treated jute exhibited better mechanical properties of all the samples. The UV radiated jute/glass fiber composite had increased tensile modulus by $33 \%$, tensile strength by $70 \%$, and tensile modulus by $33 \%$ compared with untreated composite. The increase in mechanical properties was attributed to an increase in cross-linking due to a phenomenon called photo-cross-linking, generating a high number of active sites. After a certain dose of UV radiation, mechanical properties show decrement in these mechanical properties mainly due to an opposite phenomenon-photodegradation. In photodegradation, the main cellulose chain starts to degrade and even polymer may degrade at high doses [91]. Plasma treatment was also found to be effective in improving the mechanical properties of jute fibers. In plasma treatment, new polar groups, or even polymer layers are introduced, helping the fiber to form a better adhesion with the matrix through covalent bonds. Seki et al. [92] studied the effects of oxygen plasma treatment on jute fibers. In this treatment, jute fibers were treated with radio frequencies and low frequencies through the use of different reactors. The treatment improved different mechanical properties, such as inter-laminar shear strength which was improved to 19.8 MPa for low frequency and 26.3 MPa for radio frequency oxygen plasma treatment compared to untreated jute fiber where the inter-laminar shear strength was around 11.5 MPa. This treatment also improved both flexural and tensile strengths. Radiofrequency oxygen plasma treatment was found to be much better than low frequency plasma treatment. Oxygen plasma improves fiber/matrix adhesion and interlocking due to an increase in roughness and by the fact that plasma treatment removes cellulose and hemicellulose, leaving lignin behind on the fiber surface which contributes in increasing fiber/matrix adhesion [93]. Electron-beam irradiation is an eco-friendly, clean and energy saving process to improve the surface properties of fibers, composite, films, and polymers [94]. Ji et al. [95] studied the effects of electron-beam irradiation on the mechanical and physical properties of jute fibers; 0-100 kGy (kiloGray) of electron-beam doses were used. In this study, jute fibers showed better thermal stability at the optimum dose of $10 \mathrm{kGy}$ due to increased fiber/matrix adhesion.

\section{Fiber Modification Techniques}

\subsection{Improvement in Jute Fiber and Matrix Adhesion}

The mechanical properties of any natural composite usually depend upon the dispersion of fiber in a polymeric matrix. To ensure better mechanical and physical properties, there must be a proper adhesion between fiber and matrix. A strong adhesion between fiber and matrix will help with strong interfacial bonding [96]. A lack of proper adhesion between fiber and matrix can lead to a decrease in mechanical characteristics, such as a decrease in strength [97]. The hydrophilic nature of fiber and the hydrophobic nature of matrix is also one of the main reasons for poor adhesion. This difference in nature leads to a poor stress transfer between matrix and fiber, which will further lead to different problems like the cracking of the composite and a reduction in the different properties of composites [98]. It has been presented in many studies that different techniques can be used to overcome the issues related to adhesion. The surface-modification techniques of fibers seem to achieve good results in the improvement of fiber-matrix adhesion. Many chemical and physical surface-modification techniques have been established so far as part of attempts to overcome this issue [87]. Pukanszky [99] explained a modal for the quantitative description for the reliance of tensile properties of composites on parameters such as polymer/filler adhesion and geometry. It was concluded from analysis that the ultimate tensile properties were influenced by polymer/filler adhesion and interfacial interactions. Interfacial specific surface area, surface modification, aggregation, filler and matrix properties influence the strength of composite. The proposed modal also unfolded faults and imperfections in composite such as voids, aggregation, and dewetting. All the faults and imperfections, which are directly related to the failure of composite i.e., initiation and propagation, will have impact on the tensile properties of composite. Smaller filler particles have better matrix/filler adhesion but aggregation leads to the development of the failure site, while large filler particles have poor matrix/filler which will lead to 
dewetting and cavity formation. Cavities will act as failure initiation sites. Above certain critical value of filler, matrix discontinuity will increase, leading to the brittle fracture of the composite.

Liu et al. [100] treated jute fibers with an alkali treatment (using $\mathrm{NaOH}$ ) and Maleic anhydride-grafted polypropylene (MPP) emulsion. This surface treatment method was effective in improving the performance of jute fibers in composites by increasing fiber/matrix adhesion. The method served to modify the jute fiber surface along improving fiber dispersion and increased the mechanical strength of the jute fibers, while the alkali treatment enhanced the removal of waxes and fatty constituents. The flexural, tensile, and impact strength of jute fibers were improved due to these treatments. Both of these methods were promising, showing an improvement of interfacial bonding due to an increase in adhesion between jute fiber and matrix. MPP is commonly utilized as a coupling agent to improve fiber-matrix adhesion. Combining alkali treatment and MPP show even better results in improving fiber-matrix adhesion [101]. Mohanty et al. [86] used dewaxing, alkali treatment, cyanoethylation, and grafting for the surface modification of jute fibers. Mechanical properties, such as tensile and impact strength, were also improved due to these surface modifications, along with the improvement in fiber/matrix adhesion. Mwaikambo et al. [102] treated jute fibers with an alkali solution of $\mathrm{NaOH}$. This surface technique altered the surface topology and crystallization of fibers along with enhancing the fiber/matrix adhesion. Alkali treatment made the surface rough, increasing the interlocking strength between fiber and matrix. In addition, mechanical properties were also improved due to alkalization and crystallization. Corrales et al. [103] chemically modified jute fibers by treating them with a derivative of fatty acid-oleoyl chloride. This chemical method helped in modifying the hydrophilic nature of the fiber by which fibers were left with an olefinic deposit, which resulted in improved fiber/matrix adhesion. Basak et al. [104] studied the effects of temperature on silane treatment for jute fiber surface modification. It was concluded that a high-temperature silane treatment significantly improved the mechanical properties of jute fiber when compared to a low-temperature treatment. Additionally, silane treatment helped further in improving adhesion between jute fiber and matrix. Thakur et al. [105] also used silane treatment with the help of a silane coupling agent. The silane coupling agent was found to be effective in improving the physio-chemical properties of fibers, as well as being effective for surface modification. Silane treatment increased flexural, tensile strength and Young's modulus of fibers up to $30 \%$ along with significant improvements in fiber-matrix adhesion [106]. Battegazzore et al. [107] used an interesting layer-by-layer (LBL) assembly technique to modify hemp fibers in a composite. LBL technique has been used to increase fiber/matrix adhesion through nanostructured coatings of interphase materials. LBL promotes better fiber/matrix adhesion, mass transfer, and ultimately the mechanical properties of the composite. Chitosan and sepiolite nanorods were used in composites as interphase materials and deposited LBL via water-based electrolysis. LBL deposition improved the moisture resistance of fibers, made the surface smooth, and produced nanotexturing. Nanotexturing improved fiber/matrix adhesion in the composite. A significant increase in elastic modulus and tensile strength was observed. The results of some surface treatments are also reported in Table 3.

\subsection{Moisture Absorption Properties}

The hydrophilic nature of natural fibers is one of the major hindrances faced when seeking to improve the mechanical properties of natural composites. The reason for this moisture absorption property is the presence of hydroxyl groups [69]. Moisture absorption can result in a reduction of the mechanical and physical properties, changing the dimensions [37]. In fact, the water adsorption property remains the chief hindrance in possible uses and beneficial applications. Water is absorbed by capillary actions and will also incorporate into any micro cracks and void spaces present in a bio-composite [108]. Water absorption is carried out through two methods-diffusion and percolation methods $[109,110]$. Natural fibers need to be altered physically and chemically in order to overcome this problem of moisture absorption. Different studies are available to help solve the problem of moisture absorption by giving rise to hydrophobic properties in natural fiber [34]. The durability of 
natural fiber composites has been at stake due to this absorption property, while the physical and mechanical properties of jute fiber composites have received more focus, meaning that little work has so far been done to improve the efficiency of jute fibers in hygroscopic environments. Enzyme grafting is an important technique for increasing the hydrophobic behavior of natural fiber. Grafting usually involves creation of reactive radicals through lignin oxidation. These reactive radicals act as grafting sites for oxidized or non-oxidized molecules of the choice [111,112]. Liu et al. [112] studied the effects of grafting dodecyl gallate on a jute fiber surface through HRP mediated oxidative polymerization techniques. The main goal of the research was to increase the hydrophobic characteristics of jute fibers. FTIR, SEM, and TGA confirmed surface modification through grafting, while it was observed that a hydrophobic group was introduced by a grafting agent. Hydrophobic nature was also tested through wetting time and contact angle tests. In doing so, the hydrophobic nature of jute fiber was found to be increased after surface modification. Enzymatic bonding has been studied for grafting functional molecules to lignocellulosic materials mediated by laccase. Enzymes such as laccase are emerging mediator catalysts for enzymatic grafting, having an environment friendly nature and moderate working conditions [113,114]. Dong et al. [114] studied the hydrophobic nature of jute fibers via laccase-mediated dodecyl gallate enzymatic grafting, together with exploring the feasibility of this method. Grafting and surface modification was confirmed by FTIR, SEM, XPS, and AFM, while an increase in the hydrophobic nature of jute fiber was confirmed through wetting time and the contact angle test. This research confirmed an increase in the hydrophobic nature of jute fibers after enzymatic graft surface modification, which also proved to be eco-friendly and cost-effective. In addition, surface modification increases certain mechanical properties of jute composite. Hu et al. [115] studied the different stages of moisture absorption in jute fiber/PLA composites. It was found that moisture is absorbed in three stages, including a short and abrupt moisture absorption stage, a slow and constant moisture absorption stage, and the fastest and most abrupt moisture absorption stage. A long exposure of fibers to a moisture environment would decrease their mechanical properties along with the degradation of the composite, although different types of coating can help to reduce water absorption in fiber. Many defects were found, including micro-cracks, and pore and surface relaxation during aging. Hong et al. [116] found that maleic anhydride decreased the hygroscopic behavior of jute fibers through surface modifications and by increasing the compatibility between the jute fiber and the matrix. Maleic anhydride increased the covalent bonds along with van dar Waals forces, at interfaces between the jute fiber and the matrix. Some mechanical properties were also improved due to the surface modification.

\subsection{Thermal Degradation and Fire Resistance Properties}

Flammability and thermal degradation are some of the properties of natural jute fibers that have limited the use of fibers in a vast range of applications. Flammability and combustion of any natural fiber based composite depend on factors such as composite nature, polymeric matrix, natural fibers, moisture content, thermal properties, density, and structure. Due to flammability, thermal degradation, and fire issues, natural jute fibers have not found their way into high-temperature applications [85]. It is important to understand the flammability of both fiber and polymeric matrix material. Polymeric matrix undergoes thermal and thermal oxidative decomposition during combustion. Combustion results in production of heat, dense smoke, and volatiles. These volatiles include carbon monoxide, hydrocarbons along with non-combustible and non-flammable gases such as carbon dioxide, hydrogen halides etc. Each polymer produces different volatiles and these volatiles are dependent on chemical nature of polymer. Volatiles produce free radicals which are involved in the decomposition and burning of a polymer. Final products, rate of decomposition, and the decomposition mechanism are not only dependent on the chemical nature but also on the physical properties of polymers. Physical properties such as glass-transition, decomposition, and melting temperatures impact the decomposition mechanism. At these temperatures, the polymer goes through a phase-transition which influences physical properties such as viscosity, modulus, density, and thermal conductivity. Char formation is 
another important aspect to gauge the fire and thermal decomposition of polymeric matrix. Highly cross-linked polymers or polymers which undergo cross-linking during decomposition usually form char during combustion. Char prevents heat from underlying polymer layers, acting like a heat barrier. Polymers with char formation characteristics have low flammability and high fire resistance. These polymers are, therefore, more desirable for polymeric matrix materials [117-119]. Natural fibers have decomposition temperatures less than glass transition temperatures and are called non-thermo plastics. Natural fibers have poor heat and flame resistance. Thermal degradation of natural fiber involves desorption of moisture, cellulose chains cross-linking, and the formation of volatiles, char, tar, and gases. Fibers with high cellulosic content have poor flammability and thermal degradation properties. Natural fiber is composed of cellulose, hemicellulose, lignin, pectin, waxes, and oil based materials. These all constituents take part in poor fire resistance and low temperature degradation. Temperature plays a vital role in the thermal stability of natural fibers as it controls thermal expansion and contraction and moisture sorption [120]. Low thermal stability increases the chances of cellulose degradation with the release of volatile compounds directly effecting mechanical and physical properties of natural fiber based composites [26]. Cellulose usually decomposes between the temperature range of $260-350{ }^{\circ} \mathrm{C}$, hemicellulose decomposes in between $200-260{ }^{\circ} \mathrm{C}$, lignin starts decomposing at $160^{\circ} \mathrm{C}$ and continues up to $400{ }^{\circ} \mathrm{C}$ [121]. Natural composite usually degrades completely around $400-500{ }^{\circ} \mathrm{C}$ with the release of heat and toxic compounds [122]. Burning can produce combustible gases, toxic compounds, non-combustible gases, char and smoke [123]. Differences in chemical constituents of natural fiber can change thermal degradation, fire resistance, and flame properties of natural fiber [124]. Fiber structure and fiber orientation play an important role for the determination of flammability properties [125]. The presence of ash and silica can increase fire resistance. Cellulose based materials are easily burnt in the presence of oxygen.

All natural fibers are required to pass certain tests regarding fire resistance and thermal degradation in order to be used in practical applications. Jute fibers will generate thick black smoke upon catching fire, which can have deadly consequences. To ensure smooth operation and safety, a natural jute fiber composite is needed to pass the safety test [126]. It is therefore important to understand the underlying chemistry of jute fiber in order to overcome this issue. The poor fire-resistance properties of jute fibers has kept them away from numerous applications, such as those vital for aerospace and transportation sectors. A very small number of studies have been carried out so far to improve the fire resistance of jute and natural fibers [119]. On the other hand, due to extensive research on synthetic composites, many methods have been formulated to overcome poor fire resistance. Temperature plays an important role in the thermal stability of jute fibers. A higher temperature can lead to the degradation of jute fiber and composite with decreased mechanical and physical properties [6]. Sinha et al. [127] modified the surface of jute fiber using $5 \%$ of $\mathrm{NaOH}$, with jute fibers being treated at room temperature. From DSC analysis, it was clear that the thermal stability of jute fibers decreased after treatment. The reason for the decrease in thermal stability could be down to the close packing of cellulose with resin. A long exposure time in an alkali treatment would lead to the removal of hemicellulose which will, in turn, decrease the thermal stability of jute fiber.

Nam et al. [128] modified fibers and performed silane and alkali surface treatments to increase fiber-matrix adhesion, looking to achieve a better thermal stability of jute fiber composites. Surface treatments were found to decrease weight loss during TGA analysis while increasing the thermal stability of fiber. Combustion phenomena take place when natural fibers come into contact with fire or even heat. The combustion of natural fibers depends on many factors, like the amount of oxygen, the flow of gases within the combustion area, and the heat generated during combustion [85].

Various techniques are employed to increase fire resistance in jute fibers. These techniques include the introduction of fire-resistant methods during processing [129], including coating with fire-resistance materials, the introduction of non-flammable resins, different types of polymers, a range of binders, the insulation of composite, and the introduction of nanoparticles [130]. The particle size of fire-resistant material is also important for fire-resistance properties. Some studies have even tried to use organic 
fire-retardant materials but, due to toxicity issues, they are not preferred. Some inorganic and polymeric materials are helpful for increasing the fire resistance of natural and jute fibers [131]. Fatima and Mohanty [132] studied effects of natural rubber and fire-retardant on jute composites. Jute composites with $5 \%$ natural rubber and $1 \%$ sodium phosphate as a fire-retardant exhibited least smoke density and ability to self-extinguish. Apart from jute based composites, Battegazzore et al. [133] reported interesting results for a phosphorus-based fire-retardant-ammonium dihydrogen phosphate (ADP). ADP has been reported numerous times in different research studies as a fire-retardant. Fire properties were studied for rice husk particles and hemp fiber boards. ADP protected material from heat flux by forming a carbonaceous layer preventing underlying material from oxygen, heat, and mass transfer. High content ADP samples showed the best fire-resistant properties. Matko et al. [134] studied the flame retardancy for different starch, polyurethane, and polypropylene based bio-composites. Starch based composites, with the addition of diammonium phosphate as a fire-retardant, had increased fire resistance and were more efficient than other polymers. It was concluded that increased fire resistance was attributed due to the presence of the polyol characteristic of matrix polymer and the introduction of a flame retardant. Similarly, the addition of aluminum trihydrate as a fire-retardant can delay ignition time and reduce peak heat release values [135].

Figure 4 illustrates the different phases of fire in natural fiber.

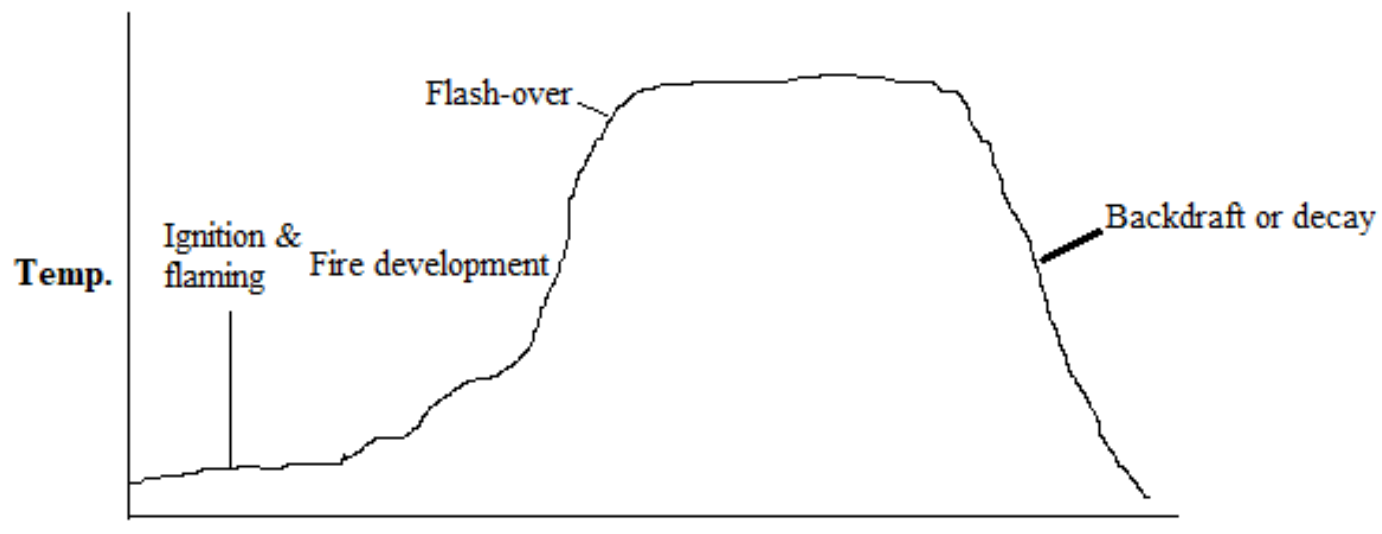

Time

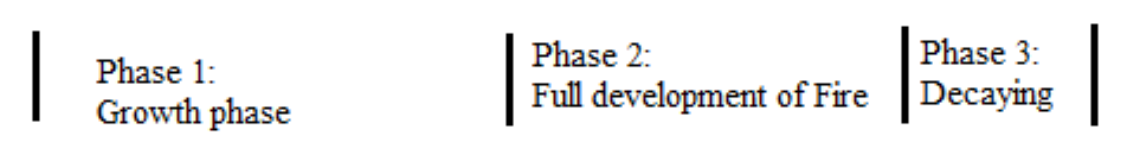

Figure 4. Different phases of fire in natural fiber. Redrawn with permission from Schartel, Hull [136] and Väisänen [3].

\section{Processing Methods for Jute-Based Composites}

Currently, bio-composites are being manufactured through conventional techniques used for production of synthetic composites. These techniques involve molding, resin transfer, compression molding, extrusion, injection, hand lay-on, spray lay-on, filament winding, and the pultrusion method [137]. These techniques have been formulated through years of industrial and research experience. Researchers have added different modifications to these techniques and even new techniques have developed but there is still capacity for much improvement to produce cost-effective and defect-free bio-composites. Bio-composites with little changes in process can be fabricated through these processes [138]. The processing route must be carefully selected to ensure proper dispersion, orientation, and aspect ratio of the fibers in the composite for desired applications [139]. The manufacturing route selection procedure also includes the consideration of the final design of the composite, size and shape, properties of raw materials, process speed and the overall cost [29]. A high aspect ratio along with uniform dispersion give rise to exceptional mechanical properties. Factors effecting manufacturing processes are moisture, fiber type, fiber contents, and fiber orientation. 
These factors also influence the final properties of composites [29]. Moisture can significantly affect processing parameters and final properties. The adequate drying of fibers is necessary before proceeding for processing. Evaporation of water moisture during processes due to high temperature can cause bubbles in final products and increase porosity of bio-composites which can deteriorate mechanical properties [140]. Different fiber modification techniques can also be used to reduce moisture content [138]. Fiber type and its contents are very important for efficient and proper processing. In addition, fiber length, aspect ratio. and compounds like silicates present in fibers have great influence on processing [141]. Temperature is the most important factor that needs to be considered in the processing of bio-composites. Natural fibers usually have a small operating window for processing. Higher temperatures can lead to the degradation of fibers [12]. For the commercial production of bio-composites apart from an abundance of natural fibers, high efficiency and easy processability of these processing techniques are required [142]. Natural bio-composites need to have good structural and functional constancy during storage, in service, and during their final environmental degradation in order to compete with synthetic composites [2]. The main advantages of natural fiber processing are that these natural fibers cause minimal damage to tools used in process. Natural fibers are less abrasive than synthetic fibers and ultimately will cause less wear to tools and machines used in processing [143]. There are a few factors which must be kept in mind during processing. Stresses induced during processing can cause premature solidification of the melt. The final shape can undergo up to $8 \%$ shrinkage upon solidification [144]. Agglomeration is another problem encountered during processing. This problem is caused due to excess fiber use. Similar fibers cling to each other and this agglomeration can cause serious effects on the final mechanical properties of the composite [12]. High viscosity of melt effects process speediness and the uniformity of final products. The uniformity of the final product is also affected by the length of fibers [145]. Problems associated with processing techniques can be overcome through the addition of many additives but these additives will increase process cost. While additives may solve some problems, they can also create new problems in processing. A number of methods can be found for manufacturing jute fiber-based bio-composites, with key final properties helping to select the best possible option. One of the driving factors during processing is a homogenous distribution of fibers in the matrix. A homogenous distribution of fibers ensures better mechanical properties, while conditions like processing temperature are mainly dependent on a polymeric matrix [146]. Additionally, many methods have been developed for the manufacturing of bio-composites.

\subsection{Hand Lay-Up Technique}

The Hand Lay-Up Technique is a widely used method for the manufacturing of different bio-composites. In this method, the fibers are placed in the mold and resin is applied on fibers with the help of rollers. For curing, a vacuum technique is usually used afterward. Some of the main advantages of this process are its simplicity, low-processing cost, and the ability to manufacture complex designs; while the process is also known for having a long processing time and being labor intensive, which are the few disadvantages associated with the process $[147,148]$. During the fabrication of jute fiber composites, this process requires up to $400 \%$ more resin than fibers which is essentially not feasible for economic purposes. Along with excessive resin consumption, the process may require a pre-treatment of fibers, adding more cost to the process. Abdullah-Al-Kafi et al. [55] manufactured a jute and glass fiber composite by employing a hand lay-up technique, from which the composite with $25 \%$ of jute fibers showed better mechanical properties. Jute and glass fiber proportions were 1:3. Chaudhary et al. [21] fabricated a jute/hemp/flax epoxy reinforced hybrid composite using the hand lay-up technique. $8 \%$ jute, $9 \%$ hemp, and $8 \%$ flax fibers by weight were used for the fabrication of the hybrid composite. 


\subsection{Resin Transfer Molding}

The process is considered to be better than hand lay-up techniques in terms of the quality of composites produced. Resin transfer molding is cost effective method with high production rate. First of all, the injection of resin material is carried out in the closed cavity mold after placement of fibers. Low vacuum pressure is applied for curing, which will be completed in 30-60 min due to vacuum. The fibers are placed in the mold prior to injection of resin. Then, after injection, fibers will impregnate in resin. Process parameters, such as injection pressure, vacuum pressure, fibers percentage, and temperature, affect the final mechanical and physical properties of the composite. This method is known for a high manufacturing rate and is ideal for the manufacturing of complex shapes. Mostly low-viscosity resins are used in this process [6,149]. Edge flow is observed in composite due to distance between fiber perform and mould cavity. Edge flow can easily disrupt the smoothness and uniformity of the flow pattern, leading to poor wetting of fibers. Edge flow can lead to defects during mould cavity filling which will lead to dry spot and spillage. The velocity of resin can vary from point to point due to non-uniformity and rough structure of fibers. This will cause voids to form which have adverse effects on the mechanical properties of the composite [150].

\subsection{Pultrusion}

Pultrusion is the best method for manufacturing composites with a thin cross-section; being a continuous manufacturing method, it is used to manufacture mats, ropes, yarn, etc. During the manufacturing of jute-based polymers and composites, jute fibers are impregnated in a resin material and then the material is passed through a hot die. In this process, it is very hard to keep fiber orientation constant. The process is known for the manufacturing of thin cross-sectional shapes and complex geometries with an allowance of high automation. Jute-based products that are manufactured via this process contain up to $70 \%$ of jute fibers. As a comparison, jute composites fabricated through this process have better mechanical properties, better electric insulation, and better corrosion resistance $[6,151]$. Akil et al. [152] studied a jute/glass fiber polyester hybrid composite. The hybrid composite was fabricated through pultrusion. The pulling speed and the die temperature were $180 \mathrm{~mm} / \mathrm{min}$ and $85^{\circ} \mathrm{C}$, respectively, for pultrusion. The jute to glass fiber ratio was $50: 50$ by volume and fibers to matrix ratio was 70:30.

\subsection{Extrusion}

Extrusion is the most popular technique used by the plastics industry, being a technique that is known to offer a uniform mixing of all components. This method is useful for manufacturing composites where the orientation of fibers is not important, as the fibers are randomly distributed. In this process, single or twin screws are used which can rotate in clockwise and anti-clockwise directions. A single-screw extruder has low mixing effects and is used in applications where less mixing of fiber and matrix material is required. A twin-screw extruder is known for a great mixing effect and high-thrust forces, working to distribute fibers uniformly throughout the composite. With extrusion, ballets are usually fed into a heated chamber with feed screws to process molten mixture and, during the extrusion process of jute composite, up to $40 \%$ of jute fibers are mixed in a polymeric matrix. After this process, the final product can be subjected to post-processing techniques for higher quality. Figure 5 shows different fabrication methods $[5,6,18]$. 


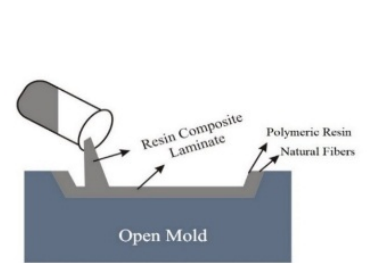

(a)

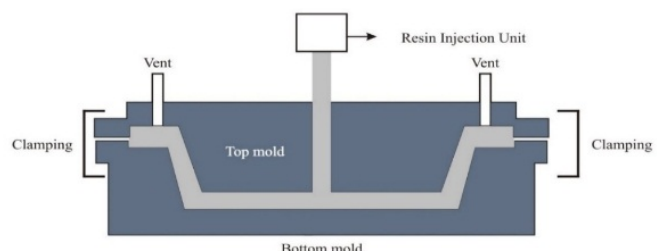

(b)

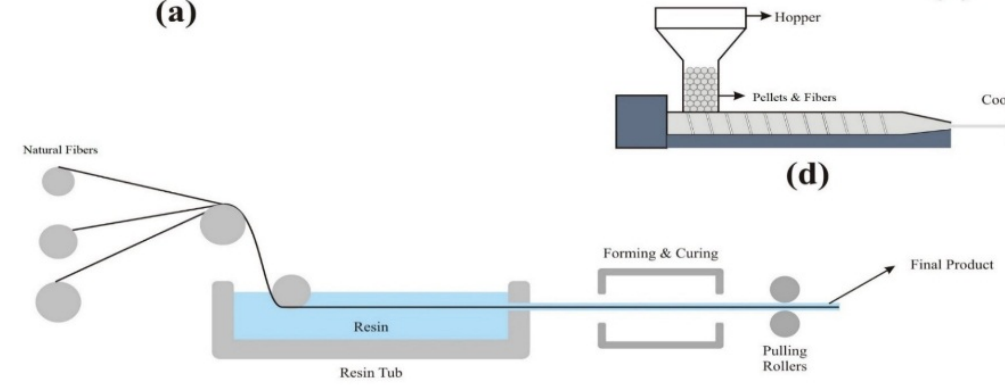

(c)

Figure 5. Different fabrication methods (a) Hand layup (b) Resin transfer molding (c) Pultrusion (d) Extrusion.

\section{Hybrid Jute Bio-Composite}

Natural fiber composites encounter various problems related to mechanical and physical properties. To overcome the shortcomings of natural fibers, synthetic fibers are introduced in composite matrix to make it a hybrid composite. Hybrid composites are simply the combination of two or more fibers in which one fiber compensates for the shortcomings of the other fiber. Usually, both natural and synthetic fibers are used to make hybrid composites. Hybrid bio-composites can also be termed as partial bio-degradable composites. Hybrid bio-composites may include non-degradable polymers with a combination of synthetic and natural fibers as fillers. Normally hybrid composites are manufactured through conventional fabrication techniques such as compression molding [2]. Hybridization of composites is generally classified into two types-intralaminate and interlaminate. In intralaminate hybridization, natural and synthetic fibers are intertwined together in one single layer while interlaminate is the deposition of different distinguishable fiber layers [153]. A fine balance between cost and performance is achievable through felicitous designing of hybrid composites. The physical and mechanical properties of hybrid composites are dependent on fiber content, length and orientation of each fiber, fiber/matrix bonding, and the failure strain of fibers. While designing and fabricating hybrid composites, the selection of suitable fibers and their properties are of utmost importance. The usefulness of a hybrid composite is determined by the physical, chemical, mechanical properties, and compatibility of fiber/matrix materials [4]. The addition of glass fibers helps in improving the shortcomings associated with natural fibers. Properties like elongation at break, impact strength, tensile strength, and Young's modulus in bio-composites can be enhanced with the hybridization of synthetic fibers. Hybridization reduces the water absorption property of bio-composites. Hybrid composites have certain advantages including high impact resistance, high toughness, and high specific strength. Composite hybridization is classified into two groups-hybrid composites with natural fibers and hybrid composites with synthetic fibers.

\subsection{Hybridization with Natural Fibers}

Composites with a combination of two or more natural fibers in a polymer matrix is known as a hybridization with natural fibers. Some of the advantages associated with natural fibers are low cost manufacturing, renewable nature, eco-friendliness, light weight, and optimum mechanical properties. Due to all these advantages, hybrid natural fiber composites are currently being used in number of 
applications such as in the automobile and aerospace industries. In general, hybrid composites have low strength to weight ratios and are easy to fabricate and manufacture [154].

Boopalan et al. [155] studied the thermal, mechanical, and water absorption properties of jute and banana fiber epoxy hybrid composites. Flexural, tensile and impact strength were at maximum for the 50/50 weight ratio of jute and banana fibers in an epoxy hybrid composite. Similarly, for the same ratio of both fibers, the hybrid composite had more enhanced thermal properties and a reduction in water absorption. Akil et al. [152] studied water uptake in a jute/glass fiber polyester hybrid composite. The addition of glass fibers increased the resistance of the composite towards water absorption. Water absorption was found to be dependent on fiber content and stacking sequence. When the hybrid composites were subjected to moisture, a significant reduction in flexural and tensile properties was observed due to water absorption. Fiore et al. [156] studied the effect of stacking sequence and sodium bi-carbonate treatment on the mechanical properties of a hybrid jute/flax epoxy composite. Sodium bi-carbonate treatment significantly improved the quasi-static properties of the hybrid composite. Sodium bi-carbonate treatment helped in improving the mechanical properties in the flax based composite, while the jute-based composite showed a slight decrease in mechanical properties. Optimum mechanical properties can be achieved through hybridization.

Jawaid et al. [157] studied chemical resistance, void content, and tensile properties for a tri-layer epoxy reinforced jute/oil palm fiber hybrid composite. Chemical resistance tests were performed using different chemicals. The hybrid composite had slightly elevated chemical resistance than the pure composite. When oil palm fiber was used as skin layer in tri-layer composite, it had a greater void content of $8.6 \%$ due to fiber/matrix compatibility issues. The jute/oil palm fiber/jute tri-layer composite had greater tensile strength as compared to when the jute fiber layer was sandwiched between oil palm fiber layers. This is due to the fact that jute fibers are more compatible with epoxy resin. In another research study, Jawaid et al. [158] studied the mechanical properties of a jute/oil palm fiber hybrid composite. The hybrid composite had increased flexural strength and modulus compared to the pure palm fiber composite. Impact strength was lower for the hybrid composite than the pure palm fiber composite. Shanmugam and Thiruchitrambalam [159] showed that alkali treated hybrid jute and palmyra palm leaf fibers had increased properties comparable with synthetic fiber hybridization such as glass fibers. Akali treated jute/palm leaf fibers based hybrid composites had increased tensile and flexural properties. Fiore et al. [160] studied the aging resistance of jute-basalt bio-epoxy hybrid composites. Sandwiched hybrid laminates exhibited high aging resistance due to basalt layers protecting jute fibers from degradation.

\subsection{Hybridization with Synthetic Fibers}

Synthetic fiber hybrid composites have better mechanical properties than natural fiber composites. Synthetic fibers have better fiber/matrix adhesion which increase the overall mechanical properties of the composite. But high cost associated with synthetic fiber manufacturing has limited the use of these hybrid composites in various applications. Some of issues related to synthetic fibers hybrid composites are environmental issues, recyclability, biodegradability, and reusability [161,162]. Research is being carried out in the field of synthetic fiber hybrid composites to overcome all the shortcomings. Researchers are looking into improving properties of natural fiber composites with the inclusion of synthetic fibers. The hybridization of natural fibers with glass fibers significantly improves the mechanical properties of the composite [154,163].

Ahmed et al. [164] studied different mechanical properties for a jute/glass fiber reinforced polyester hybrid composite. Young's modulus increased with the increase in glass fiber content while the Poisson ratio decreased. This was due to more transverse strain and lower longitudinal strain in the jute fiber composite in comparison with the jute/glass fiber composite. Aquino et al. [165] studied the effects of moisture on different mechanical properties of a jute/glass fiber hybrid composite. Moisture content decreased mechanical properties such as tensile strength and Young's modulus. Moisture disrupts fiber/matrix adhesion with decrease in mechanical properties. Selver et al. [166] studied the 
effect of stacking arrangement on different mechanical properties of a jute/flax/glass fiber thermoset composite. The addition of natural fibers reduced overall density for both jute/glass and flax/glass fiber composites. Higher flexural strength was obtained when glass fibers were used as outer layers, sandwiching natural fiber layer.

\section{Limitations of Jute Fiber}

Despite a lot of research being carried out to make use of jute fibers in many practical applications, many limitations still need to be addressed to get the full benefit from them. Some shortcomings of jute fibers include the hydrophilic nature of the fiber, poor fiber-matrix adhesion, the poor dispersion of jute fiber in a matrix, low physical and mechanical properties, flammable properties, limitations in thermal properties, a short temperature window for processing, and a lack of processing techniques [84,85,167]. These are some of the limitations keeping jute fibers from many applications, especially in load-bearing examples. Different scientists and researchers have developed fiber-modification techniques to overcome these issues. Jute fiber is hydrophilic in nature and vulnerable to absorbing water from the external environment. Hydroxyl and the presence of polar groups in jute fiber are responsible for the absorption of excess moisture. The moisture absorption in jute fiber can cause it to swell, which can further lead to the cracking of bio-composites. This moisture is also believed to cause compatibility issues with fiber and matrix. Poor fiber-matrix adhesion, a decrease in interfacial bonding, and a decrease in mechanical properties are some of the consequences of moisture absorption [97,167]. The hydrophobic nature of matrix material and the hydrophilic nature of fibers cause poor fiber-matrix adhesion in bio-composites. Different chemical methods are currently being used to overcome issues related to the hydrophilic nature of the fibers. Jute fiber composite usually has low mechanical properties when compared with synthetic fibers such as carbon and glass fibers. Much focus is being given on improving these mechanical properties to increase the implementation of jute fiber composites and polymers [168]. Different modification treatments can be applied to achieve such a goal. Researchers have found these treatments to be useful in improving different mechanical and physical properties [169]. Jute fibers are a natural fiber, containing pectin, lignin, oils, and different waxes. These constituents are all highly combustible and flammable in favorable conditions, making jute fiber poorly resistant to fire. The flammability issue is one of the major hindrances affecting the implementation of these fibers in practical use. However, the addition of flame retardants seems to be improving the flammability properties of these fibers, but much research is still required if this problem is to be overcome effectively. A high concentration of cellulose in jute fiber makes it more susceptible to fire [124]. Thermal degradation is another problem associated with these jute fibers, which can easily be degraded around a temperature of $450{ }^{\circ} \mathrm{C}$, which limits jute fiber for low-temperature applications. This degradation will lead to drastic changes in the mechanical and physical properties of fibers [41]. Amount of jute fiber constituents such as cellulose, pectin, oil, and waxes can vary from plant to plant and are due to different external environmental factors. These amounts effect both thermal and fire properties, while fiber direction and structure also play an effective role in changing these properties. The high-cellulose composition makes fibers less fire-resistant, while low lignin concentration gives better fire resistance [125]. A lack of processing techniques for jute-based bio-composites is another issue. Currently, with little modifications, conventional techniques used for the production of synthetic composites and polymers are favored. However, new processing techniques are being developed to ensure the smooth processing of jute-based bio-composites.

\section{Applications}

Jute fiber has a vast range of applications and become one of the most important fibers in the bio-composite industry. Jute fiber somehow has better mechanical and physical properties than other natural fibers. Countries like Sri Lanka, Bangladesh, Malaysia, and Indonesia offer a high supply of jute fiber plants, making it abundant in nature. Currently, the textile industry is the main user of jute fiber, which is used to make clothes, ropes, bedsheets, sacks, bags, shoelaces, etc. Significantly, jute fiber 
has also made its way to the automobile sector, where it is used to make cup holders, different parts of the dashboard, and door panels. In the USA, many big companies have been using natural fibers like jute, hemp, and flex for making different exterior and interior parts for vehicles [170]. Jute fibers can help different car manufacturing companies to reduce weight and to improve mileage. Many big companies like BMW and Mercedes are taking the initiative and investing in research and development to make the best use of natural fibers in their cars. Furthermore, jute fibers have found applications in packaging industries and are replacing synthetic fibers, as well as being used in cosmetics, in the medical sector, and even in paints industries for various diversified applications.

Many developed countries are themselves taking radical steps to incorporate natural fibers into different industries, aiming for a clean environment. Jute fibers are readily used in construction for the manufacturing of windows, doors, floor matting, partitions between rooms, and for ceilings. They are even being used to make chairs, tables, and different kitchen products. European countries are more concerned with environmental changes and governments are desperately trying to introduce natural fibers like jute fiber into practical applications. For this purpose, many government and private organizations have joined hands for the commercialization of these fibers. Governments are giving different incentives to industries for the use of natural fibers in the manufacturing of products [171]. In addition, jute fiber is employed in agriculture and consumer goods industries for various applications. The use of various natural fibers, including jute fiber, will continue to increase in the coming few years, offering lots of potential to be used in a number of applications. In addition, jute fibers are renewable and eco-friendly in nature [172]. Although jute fiber is considered as one of the most popular fibers, a lot of effort is still required to make the best use of it in different applications. Some of the main reasons for the slow commercialization of jute fiber include a lack of processing methods, low mechanical and physical properties in comparison with synthetic fibers, and the high costs associated with jute fiber composites $[6,24]$. Research studies are being carried out to make jute fiber a better fit for its potential applications. Due to a huge number of potential applications, many industries are taking a fresh interest in jute fibers. Asia has become a hub for the production of jute fiber and many new markets are emerging throughout the region. It is anticipated that the demand for jute fiber will increase significantly in the near future due to vast applications. Consumers are accepting jute fiber composites due to its excellent properties and preferring its products due to minimal environmental effects. Figure 6 shows the different applications of jute-based composites.

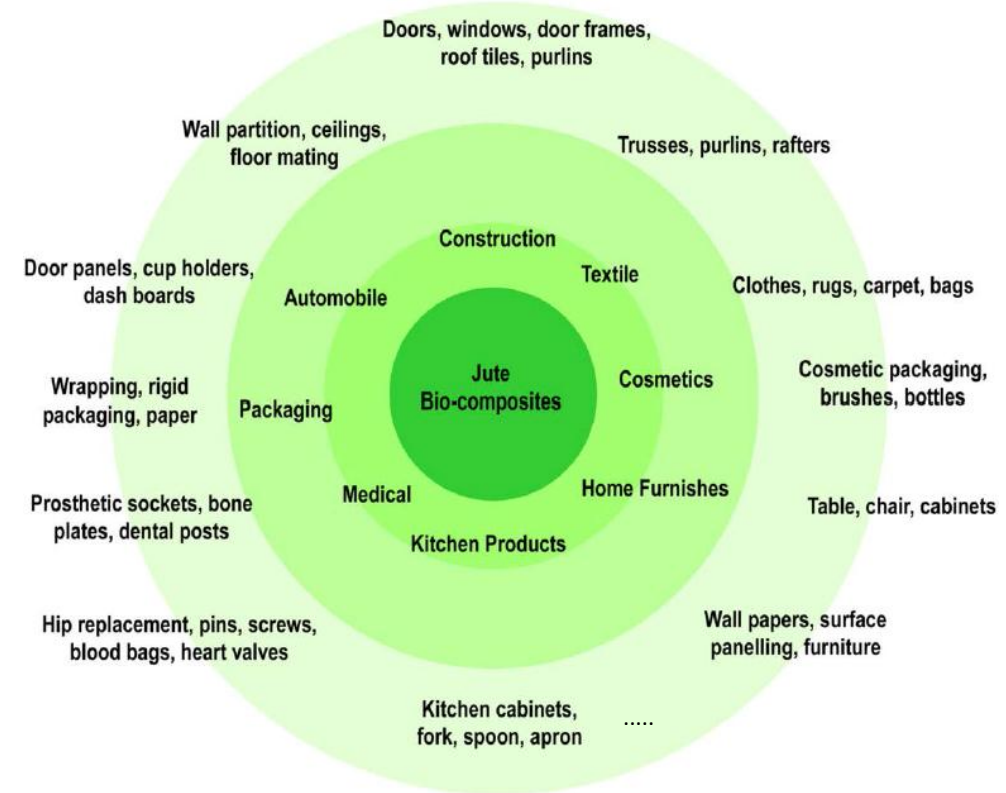

Figure 6. Applications of jute-based composites. 


\section{Conclusions}

The enormous potential of jute-based composites to provide environmentally-friendly materials is the key driving force behind their fast development. The concept of bio-composites is not new, rather the term "green composites" has been tossed around by a number of studies before. Initially, high fabrication costs and a lack of synthesis methods have restricted the growth of bio-composites, but environmental concerns have raised their importance. Jute-based composites have attracted the attention of many researchers, together with research and development funds, due to their better physical and mechanical properties among all natural fibers.

This review depicts the different problems linked with an excessive use of synthetic composites. These problems include pollution, disposal problems, inertness, and the high-carbon emissions associated with their use. It is concluded that the matter of discontinuing and discouraging the manufacturing of synthetic composites is of absolute importance for protecting the environment from their hazards. In this work, we have presented a critical analysis and some key findings concerning recent jute-based bio and hybrid composites. These key findings include discussion of different fabrication techniques for jute-based composites, such as hand lay-up, resin transfer molding, pultrusion and extrusion, and detailed discussion regarding the physical, mechanical, and electrical issues, as well as flammability and moisture absorption properties. The structure of jute fibers has been discussed, describing all the constituents and the part they play in its properties. It was determined that micro-fibrils and lumen play vital roles in both the mechanical properties and low density. Different bonding structures were also discussed, explaining their roles in better mechanical properties. A few of the significant limitations of jute-based composites include poor fiber-matrix adhesion and the hydrophilic nature of the fiber. These limitations can be overcome through different physical-chemical and chemical-modification techniques. These modification techniques help in improving poor fiber-matrix adhesion, the hydrophilic nature, and the poor thermal properties of jute fibers. Different surface-modification techniques, such as alkali and radiation techniques, were also found to be useful in increasing the mechanical properties and minimizing the limitations of jute-based composites. Another way to overcome these limitations is the inclusion of synthetic fibers to make hybrid jute-based composites. Hybrid jute-based composites have better mechanical and physical properties. Hybrid jute-based composites have improved fiber/matrix adhesion, better resistance for moisture, and enhanced thermal properties.

This study also outlines the various applications of jute-based composites, such as textiles, construction, packaging, medical, cosmetic, and furniture industries. Due to the growing demand for jute-based composites, the applications are likely to include new fields and it is expected that their usage will be increased significantly, followed by their detailed research and development for industrial-scale processes.

Author Contributions: This review study was conceptualized with cooperation among all authors; M.A.A. and A.B. designed the review topic and performed literature search. M.Z. and M.T.M. handled the writing and editing of the manuscript. R.K. and A.B. assisted with the development of tables and figures from the data analysis.

Funding: This article was funded by the Deanship of Scientific Research (DSR) at King Abdulaziz University, Jeddah. The author, therefore, acknowledges with thanks DSR for technical and financial support.

Conflicts of Interest: The authors declare no conflict of interest.

\section{References}

1. dos Santos Rosa, D.; Lenz, D.M. Biocomposites: Influence of matrix nature and additives on the properties and biodegradation behaviour. Biodegrad. Eng. Technol. 2013. [CrossRef]

2. Satyanarayana, K.G.; Arizaga, G.G.; Wypych, F.; Arizaga, G.G.C. Biodegradable composites based on lignocellulosic fibers-An overview. Prog. Polym. Sci. 2009, 34, 982-1021. [CrossRef]

3. Väisänen, T.; Das, O.; Tomppo, L. A review on new bio-based constituents for natural fiber-polymer composites. J. Clean. Prod. 2017, 149, 582-596. [CrossRef] 
4. John, M.J.; Thomas, S. Biofibres and biocomposites. Carbohydr. Polym. 2008, 71, 343-364. [CrossRef]

5. Burrola-Núñez, H.; Herrera-Franco, P.J.; Rodríguez-Félix, D.E.; Soto-Valdez, H.; Madera-Santana, T.J. Surface modification and performance of jute fibers as reinforcement on polymer matrix: An overview. J. Nat. Fibers 2018, 1-17. [CrossRef]

6. Iman, M.; Maji, T.K. Jute: An Interesting Lignocellulosic Fiber for New Generation Applications. Lignocellul. Polym. Compos. 2014, 3, 453-475.

7. Kozlowski, R.; Wladyka-Przybylak, M. Uses of natural fiber reinforced plastics. In Natural Fibers, Plastics and Composites; Springer: Berlin, Germany, 2004; pp. 249-274.

8. Satyanarayana, K.G.; Flores-Sahagun, T.H.; Bowman, P. Lignocellulosic Materials of Brazil-Their Characterization and Applications in Polymer Composites and Art Works. In Lignocellulosic Composite Materials; Springer: Berlin, Germany, 2018; pp. 1-96.

9. Welcome to the World of Jute and Kenaf-IJSG. Available online: http://www.jute.org/plant.htm (accessed on 27 June 2018).

10. Mir, R.R.; Rustgi, S.; Sharma, S.; Singh, R.; Goyal, A.; Kumar, J.; Gaur, A.; Tyagi, A.K.; Khan, H.; Sinha, M.K.; et al. A preliminary genetic analysis of fibre traits and the use of new genomic SSRs for genetic diversity in jute. Euphytica 2008, 161, 413-427. [CrossRef]

11. Li, X.; Tabil, L.G.; Panigrahi, S. Chemical Treatments of Natural Fiber for Use in Natural Fiber-Reinforced Composites: A Review. J. Polym. Environ. 2007, 15, 25-33. [CrossRef]

12. Pickering, K.; Efendy, M.A.; Le, T. A review of recent developments in natural fibre composites and their mechanical performance. Compos. Part A Appl. Sci. Manuf. 2016, 83, 98-112. [CrossRef]

13. Wang, P.; Chen, F.; Zhang, H.; Meng, W.; Sun, Y.; Liu, C. Large-scale preparation of jute-fiber-reinforced starch-based composites with high mechanical strength and optimized biodegradability. Starch Stärke 2017, 69, 1700052. [CrossRef]

14. Jahan, M.S.; Saeed, A.; He, Z.; Ni, Y. Jute as raw material for the preparation of microcrystalline cellulose. Cellulose 2011, 18, 451-459. [CrossRef]

15. Monteiro, S.N.; Lopes, F.P.D.; Ferreira, A.S.; Nascimento, D.C.O. Natural-fiber polymer-matrix composites: Cheaper, tougher, and environmentally friendly. JOM 2009, 61, 17-22. [CrossRef]

16. Suddell, B.C.; Evans, W.J.; Isaac, D.H.; Crosky, A. A survey into the application of natural fiber composites in the automotive industry. In Proceedings of the 4th International Symposium on Natural Polymers and Composites-ISNAPol, São Pedro, SP, Brazil, 10-11 April 2002; pp. 455-461.

17. Pickering, K.L. Properties and Performance of Natural-Fibre Composites; Elsevier: Amsterdam, The Netherlands, 2008.

18. Faruk, O.; Bledzki, A.K.; Fink, H.-P.; Sain, M. Biocomposites reinforced with natural fibers: 2000-2010. Prog. Polym. Sci. 2012, 37, 1552-1596. [CrossRef]

19. PressReader.com-Connecting People Through News. Available online: https://www.pressreader.com/ philippines/manila-bulletin/20170619/281938837908620 (accessed on 11 May 2018).

20. Top Jute Producing Countries in the World. In: World Atlas. Available online: https://www.worldatlas.com/ articles/top-jute-producing-countries-in-the-world.html (accessed on 11 May 2018).

21. Chaudhary, V.; Bajpai, P.K.; Maheshwari, S. Studies on Mechanical and Morphological Characterization of Developed Jute/Hemp/Flax Reinforced Hybrid Composites for Structural Applications. J. Nat. Fibers 2018, 15, 80-97. [CrossRef]

22. Abraham, E.; Deepa, B.; Pothan, L.; Jacob, M.; Thomas, S.; Cvelbar, U.; Anandjiwala, R. Extraction of nanocellulose fibrils from lignocellulosic fibres: A novel approach. Carbohydr. Polym. 2011, 86, 1468-1475. [CrossRef]

23. Vilay, V.; Mariatti, M.; Taib, R.M.; Todo, M. Effect of fiber surface treatment and fiber loading on the properties of bagasse fiber-reinforced unsaturated polyester composites. Compos. Sci. Technol. 2008, 68, 631-638. [CrossRef]

24. Roe, P.J.; Ansell, M.P. Jute-reinforced polyester composites. J. Mater. Sci. 1985, 20, 4015-4020. [CrossRef]

25. Biagiotti, J.; Puglia, D.; Kenny, J.M. A review on natural fibre-based composites-part I: Structure, processing and properties of vegetable fibres. J. Nat. Fibers 2004, 1, 37-68. [CrossRef]

26. Jawaid, M.; Khalil, H.A. Cellulosic/synthetic fibre reinforced polymer hybrid composites: A review. Carbohydr. Polym. 2011, 86, 1-18. [CrossRef]

27. Reddy, N.; Yang, Y. Biofibers from agricultural byproducts for industrial applications. Trends Biotechnol. 2005, 23, 22-27. [CrossRef] 
28. Guillén, F.; Martínez, M.J.; Gutiérrez, A.; Del Rio, J.C. Biodegradation of lignocellu-losics: Microbial, chemical, and enzymatic aspects of the fungal attack of lignin. Int. Microbiol. 2005, 8, 195-204.

29. Faruk, O.; Bledzki, A.K.; Fink, H.-P.; Sain, M. Progress report on natural fiber reinforced composites. Macromol. Mater. Eng. 2014, 299, 9-26. [CrossRef]

30. Khalil, H.A.; Davoudpour, Y.; Islam, M.N.; Mustapha, A.; Sudesh, K.; Dungani, R.; Jawaid, M. Production and modification of nanofibrillated cellulose using various mechanical processes: A review. Carbohydr. Polym. 2014, 99, 649-665. [CrossRef] [PubMed]

31. Kalia, S.; Dufresne, A.; Cherian, B.M.; Kaith, B.S.; Avérous, L.; Njuguna, J.; Nassiopoulos, E. Cellulose-Based Bio- and Nanocomposites: A Review. Int. J. Polym. Sci. 2011. [CrossRef]

32. Khalil, H.A.; Bhat, A.; Yusra, A.I. Green composites from sustainable cellulose nanofibrils: A review. Carbohydr. Polym. 2012, 87, 963-979. [CrossRef]

33. Mohanty, A.K.; Misra, M.; Hinrichsen, G. Biofibers, biodegradable polymers and biocomposites: An overview. Macromol. Mater. Eng. 2000, 276, 1-24. [CrossRef]

34. Akil, H.M.; Cheng, L.W.; Ishak, Z.M.; Abu Bakar, A.; Rahman, M.A. Water absorption study on pultruded jute fibre reinforced unsaturated polyester composites. Compos. Sci. Technol. 2009, 69, 1942-1948. [CrossRef]

35. Klemm, D.; Philipp, B.; Heinze, T.; Heinze, U.; Wagenknecht, W. General considerations on structure and reactivity of cellulose: Section 2.1-2.1. Wiley Online Library 2004, 4. [CrossRef]

36. Gopinath, A.; Kumar, M.S.; Elayaperumal, A. Experimental Investigations on Mechanical Properties of Jute Fiber Reinforced Composites with Polyester and Epoxy Resin Matrices. Procedia Eng. 2014, 97, 2052-2063. [CrossRef]

37. Célino, A.; Freour, S.; Jacquemin, F.; Casari, P. The hygroscopic behavior of plant fibers: A review. Front. Chem. 2014, 1. [CrossRef]

38. Fratzl, P. Cellulose and collagen: From fibres to tissues. Curr. Opin. Colloid Interface Sci. 2003, 8, 32-39. [CrossRef]

39. Roy, S.; Lutfar, L.B. 3-Bast fibres: Jute. In Handbook of Natural Fibres; Kozłowski, R.M., Ed.; Woodhead Publishing: Sawston, UK, 2012; pp. 24-46.

40. Jayamani, E.; Hamdan, S.; Rahman, M.R.; Bin Bakri, M.K. Comparative Study of Dielectric Properties of Hybrid Natural Fiber Composites. Procedia Eng. 2014, 97, 536-544. [CrossRef]

41. Yan, L.; Kasal, B.; Huang, L. A review of recent research on the use of cellulosic fibres, their fibre fabric reinforced cementitious, geo-polymer and polymer composites in civil engineering. Compos. Part B Eng. 2016, 92, 94-132. [CrossRef]

42. Hansen, C.M.; Björkman, A. The Ultrastructure of Wood from a Solubility Parameter Point of View. Holzforsch Int. J. Biol. Chem. Phys. Technol. Wood 2009, 52, 335-344. [CrossRef]

43. Rowell, R.M.; Han, J.S.; Rowell, J.S. Characterization and factors effecting fiber properties. Nat. Polym. Agrofibers Based Compos. 2000, 2000, 115-134.

44. Norgren, M.; Edlund, H. Lignin: Recent advances and emerging applications. Curr. Opin. Colloid Interface Sci. 2014, 19, 409-416. [CrossRef]

45. Kumar, M.N.S.; Mohanty, A.K.; Erickson, L.; Misra, M. Lignin and Its Applications with Polymers. J. Biobased Mater. Bioenergy 2009, 3, 1-24. [CrossRef]

46. Gurunathan, T.; Mohanty, S.; Nayak, S.K. A review of the recent developments in biocomposites based on natural fibres and their application perspectives. Compos. Part A Appl. Sci. Manuf. 2015, 77, 1-25. [CrossRef]

47. Mishra, V.; Biswas, S. Physical and Mechanical Properties of Bi-directional Jute Fiber Epoxy Composites. Procedia Eng. 2013, 51, 561-566. [CrossRef]

48. Thwe, M.M.; Liao, K. Durability of bamboo-glass fiber reinforced polymer matrix hybrid composites. Compos. Sci. Technol. 2003, 63, 375-387. [CrossRef]

49. Fu, S.-Y.; Xu, G.; Mai, Y.-W. On the elastic modulus of hybrid particle/short-fiber/polymer composites. Compos. Part B Eng. 2002, 33, 291-299. [CrossRef]

50. Fiore, V.; Scalici, T.; Sarasini, F.; Tirilló, J.; Calabrese, L. Salt-fog spray aging of jute-basalt reinforced hybrid structures: Flexural and low velocity impact response. Compos. Part B Eng. 2017, 116, 99-112. [CrossRef]

51. Ho, M.-P.; Wang, H.; Lee, J.-H.; Ho, C.-K.; Lau, K.-T.; Leng, J.; Hui, D. Critical factors on manufacturing processes of natural fibre composites. Compos. Part B Eng. 2012, 43, 3549-3562. [CrossRef] 
52. Chollakup, R.; Tantatherdtam, R.; Ujjin, S.; Sriroth, K. Pineapple leaf fiber reinforced thermoplastic composites: Effects of fiber length and fiber content on their characteristics. J. Appl. Polym. Sci. 2011, 119, 1952-1960. [CrossRef]

53. Lodha, P.; Netravali, A.N. Characterization of interfacial and mechanical properties of "green" composites with soy protein isolate and ramie fiber. J. Mater. Sci. 2002, 37, 3657-3665. [CrossRef]

54. Mishra, H.K.; Dash, B.N.; Tripathy, S.S.; Padhi, B.N. A study on mechanical performance of jute-epoxy composites. Polym. Technol. Eng. 2000, 39, 187-198. [CrossRef]

55. Abdullah-Al-Kafi; Abedin, M.Z.; Beg, M.D.H.; Pickering, K.L.; Khan, M.A. Study on the mechanical properties of jute/glass fiber-reinforced unsaturated polyester hybrid composites: Effect of surface modification by ultraviolet radiation. J. Reinf. Plast. Compos. 2006, 25, 575-588. [CrossRef]

56. Ahmed, K.S.; Vijayarangan, S. Tensile, flexural and interlaminar shear properties of woven jute and jute-glass fabric reinforced polyester composites. J. Mater. Process. Technol. 2008, 207, 330-335. [CrossRef]

57. Ahmed, K.S.; Vijayarangan, S.; Rajput, C. Mechanical Behavior of Isothalic Polyester-based Untreated Woven Jute and Glass Fabric Hybrid Composites. J. Reinf. Plast. Compos. 2006, 25, 1549-1569. [CrossRef]

58. Gibeop, N.; Lee, D.; Prasad, C.; Toru, F.; Kim, B.S.; Song, J.I. Effect of plasma treatment on mechanical properties of jute fiber/poly (lactic acid) biodegradable composites. Adv. Compos. Mater. 2013, 22, 389-399. [CrossRef]

59. Zamri, M.H.; Akil, H.M.; Bakar, A.A.; Ishak, Z.A.M.; Cheng, L.W. Effect of water absorption on pultruded jute/glass fiber-reinforced unsaturated polyester hybrid composites. J. Compos. Mater. 2012, 46, 51-61. [CrossRef]

60. Goriparthi, B.K.; Suman, K.; Rao, N.M. Effect of fiber surface treatments on mechanical and abrasive wear performance of polylactide/jute composites. Compos. Part A Appl. Sci. Manuf. 2012, 43, 1800-1808. [CrossRef]

61. Rezaur Rahman, M.; Hasan, M.; Monimul Huque, M.; Nazrul Islam, M. Physico-mechanical properties of jute fiber reinforced polypropylene composites. J. Reinf. Plast. Compos. 2010, 29, 445-455. [CrossRef]

62. Boopalan, M.; Umapathy, M.J.; Jenyfer, P. A Comparative Study on the Mechanical Properties of Jute and Sisal Fiber Reinforced Polymer Composites. Silicon 2012, 4, 145-149. [CrossRef]

63. Joshy, M.K.; Mathew, L.; Joseph, R. Influence of Fiber Surface Modification on the Mechanical Performance of Isora-Polyester Composites. Int. J. Polym. Mater. 2008, 58, 2-20. [CrossRef]

64. Lilholt, H.; Lawther, J.M. 1.10-Natural Organic Fibers. In Comprehensive Composite Materials; Kelly, A., Zweben, C., Eds.; Pergamon: Oxford, UK, 2000; pp. 303-325.

65. Rowell, R.M.; Sanadi, A.R.; Caulfield, D.F.; Jacobson, R.E. Utilization of natural fibers in plastic composites: Problems and opportunities. Lignocellul. Plast Compos. 1997, 13, 23-51.

66. Stokke, D.D.; Wu, Q.; Han, G. Introduction to Wood and Natural Fiber Composites; John Wiley \& Sons: Hoboken, NJ, USA, 2013.

67. Ramesh, M.; Palanikumar, K.; Reddy, K.H. Mechanical property evaluation of sisal-jute-glass fiber reinforced polyester composites. Compos. Part B Eng. 2013, 48, 1-9. [CrossRef]

68. Ramesh, M.; Palanikumar, K.; Reddy, K.H. Comparative Evaluation on Properties of Hybrid Glass Fiber-Sisal/Jute Reinforced Epoxy Composites. Procedia Eng. 2013, 51, 745-750. [CrossRef]

69. Kalia, S.; Kaith, B.; Kaur, I. Pretreatments of natural fibers and their application as reinforcing material in polymer composites-A review. Polym. Eng. Sci. 2009, 49, 1253-1272. [CrossRef]

70. Wambua, P.; Ivens, J.; Verpoest, I. Natural fibres: Can they replace glass in fibre reinforced plastics? Compos. Sci. Technol. 2003, 63, 1259-1264. [CrossRef]

71. Monteiro, S.N.; Lopes, F.P.D.; Barbosa, A.P.; Bevitori, A.B.; Da Silva, I.L.A.; Da Costa, L.L. Natural Lignocellulosic Fibers as Engineering Materials-An Overview. Met. Mater. Trans. A 2011, 42, 2963-2974. [CrossRef]

72. Satyanarayana, K.; Guimarães, J.; Wypych, F. Studies on lignocellulosic fibers of Brazil. Part I: Source, production, morphology, properties and applications. Compos. Part A Appl. Sci. Manuf. 2007, 38, 1694-1709. [CrossRef]

73. Dufresne, A. Cellulose-based composites and nanocomposites. In Monomers, Polymers and Composites from Renewable Resources; Elsevier: Amsterdam, The Netherlands, 2008; pp. 401-418.

74. Dittenber, D.B.; GangaRao, H.V. Critical review of recent publications on use of natural composites in infrastructure. Compos. Part A Appl. Sci. Manuf. 2012, 43, 1419-1429. [CrossRef] 
75. Dicker, M.P.; Duckworth, P.F.; Baker, A.B.; François, G.; Hazzard, M.K.; Weaver, P.M. Green composites: A review of material attributes and complementary applications. Compos. Part A Appl. Sci. Manuf. 2014, 56, 280-289. [CrossRef]

76. Rathore, A.; Pradhan, M.; Pradhan, M. Hybrid Cellulose Bionanocomposites from banana and jute fibre: A Review of Preparation, Properties and Applications. Mater. Today Proc. 2017, 4, 3942-3951. [CrossRef]

77. Cheung, H.-Y.; Ho, M.-P.; Lau, K.-T.; Cardona, F.; Hui, D. Natural fibre-reinforced composites for bioengineering and environmental engineering applications. Compos. Part B Eng. 2009, 40, 655-663. [CrossRef]

78. Zini, E.; Scandola, M. Green composites: An overview. Polym. Compos. 2011, 32, 1905-1915. [CrossRef]

79. Tripathi, P.; Gupta, V.K.; Dixit, A.; Mishra, R.K.; Sharma, S. Development and characterization of low cost jute, bagasse and glass fiber reinforced advanced hybrid epoxy composites. AIMS Mater. Sci. 2018, 5, 320-337. [CrossRef]

80. Jha, K.; Samantaray, B.B.; Tamrakar, P. A Study on Erosion and Mechanical Behavior of Jute/E-Glass Hybrid Composite. Mater. Today Proc. 2018, 5, 5601-5607. [CrossRef]

81. Anand, P.; Rajesh, D.; Kumar, M.S.; Raj, I.S. Investigations on the performances of treated jute/Kenaf hybrid natural fiber reinforced epoxy composite. J. Polym. Res. 2018, 25, 94. [CrossRef]

82. Motaleb, K.A. Improvement of Mechanical Properties by Alkali Treatment on Pineapple and Jute Fabric Reinforced Polyester Resin Composites. Int J. Compos. Mater. 2018, 8, 32-37.

83. Athijayamani, A.; Thiruchitrambalam, M.; Natarajan, U.; Pazhanivel, B. Effect of moisture absorption on the mechanical properties of randomly oriented natural fibers/polyester hybrid composite. Mater. Sci. Eng. A 2009, 517, 344-353. [CrossRef]

84. Kozlowski, R.; Władyka-Przybylak, M.; Władyka-Przybylak, M. Flammability and fire resistance of composites reinforced by natural fibers. Polym. Adv. Technol. 2008, 19, 446-453. [CrossRef]

85. Mohanty, A.; Khan, M.A.; Hinrichsen, G. Surface modification of jute and its influence on performance of biodegradable jute-fabric/Biopol composites. Compos. Sci. Technol. 2000, 60, 1115-1124. [CrossRef]

86. Mohanty, A.K.; Misra, M.; Drzal, L.T. Surface modifications of natural fibers and performance of the resulting biocomposites: An overview. Compos. Interfaces 2001, 8, 313-343. [CrossRef]

87. Braga, R.; Magalhaes, P. Analysis of the mechanical and thermal properties of jute and glass fiber as reinforcement epoxy hybrid composites. Mater. Sci. Eng. C 2015, 56, 269-273. [CrossRef] [PubMed]

88. Khan, M.A.; Haque, N.; Al-Kafi, A.; Alam, M.N.; Abedin, M.Z. Jute Reinforced Polymer Composite by Gamma Radiation: Effect of Surface Treatment with UV Radiation. Polym. Technol. Eng. 2006, 45, 607-613. [CrossRef]

89. Khan, R.A.; Khan, M.A.; Khan, A.H.; Hossain, M.A. Effect of gamma radiation on the performance of jute fabrics-reinforced polypropylene composites. Radiat. Phys. Chem. 2009, 78, 986-993.

90. Islam, T.; Khan, R.A.; Khan, M.A.; Rahman, M.A.; Fernandez-Lahore, M.; Huque, Q.M.I.; Islam, R.; Lahore, H.M.F. Physico-Mechanical and Degradation Properties of Gamma-Irradiated Biocomposites of Jute Fabric-Reinforced Poly(caprolactone). Polym. Technol. Eng. 2009, 48, 1198-1205. [CrossRef]

91. Hassan, M.M.; Islam, M.R.; Shehrzade, S.; Khan, M.A. Influence of Mercerization Along with Ultraviolet (UV) and Gamma Radiation on Physical and Mechanical Properties of Jute Yarn by Grafting with 3-(Trimethoxysilyl) Propylmethacrylate (Silane) and Acrylamide Under UV Radiation. Polym. Technol. Eng. 2003, 42, 515-531. [CrossRef]

92. Seki, Y.; Sarikanat, M.; Sever, K.; Erden, S.; Gulec, H.A. Effect of the low and radio frequency oxygen plasma treatment of jute fiber on mechanical properties of jute fiber/polyester composite. Fibers Polym. 2010, 11, 1159-1164. [CrossRef]

93. Yuan, X.; Jayaraman, K.; Bhattacharyya, D. Effects of plasma treatment in enhancing the performance of woodfibre-polypropylene composites. Compos. Part A Appl. Sci. Manuf. 2004, 35, 1363-1374. [CrossRef]

94. Pang, Y.; Cho, D.; Han, S.O.; Park, W.H. Interfacial shear strength and thermal properties of electron beam-treated henequen fibers reinforced unsaturated polyester composites. Macromol. Res. 2005, 13, 453-459. [CrossRef]

95. Ji, S.G.; Hwang, J.H.; Cho, D.; Kim, H.-J. Influence of electron beam treatment of jute on the thermal properties of random and two-directional jute/poly(lactic acid) green composites. J. Adhes. Sci. Technol. 2013, 27, 1359-1373. [CrossRef] 
96. Signori, F.; Pelagaggi, M.; Bronco, S.; Righetti, M.C. Amorphous/crystal and polymer/filler interphases in biocomposites from poly(butylene succinate). Thermochim. Acta 2012, 543, 74-81. [CrossRef]

97. John, M.J.; Anandjiwala, R.D. Recent developments in chemical modification and characterization of natural fiber-reinforced composites. Polym. Compos. 2008, 29, 187-207. [CrossRef]

98. Fiore, V.; Di Bella, G.; Valenza, A. The effect of alkaline treatment on mechanical properties of kenaf fibers and their epoxy composites. Compos. Part B Eng. 2015, 68, 14-21. [CrossRef]

99. Pukánszky, B. Influence of interface interaction on the ultimate tensile properties of polymer composites. Composites 1990, 21, 255-262. [CrossRef]

100. Liu, X. Surface modification and micromechanical properties of jute fiber mat reinforced polypropylene composites. Express Polym. Lett. 2007, 1, 299-307. [CrossRef]

101. Mohanty, A.K.; Drzal, L.T.; Misra, M. Novel hybrid coupling agent as an adhesion promoter in natural fiber reinforced powder polypropylene composites. J. Mater. Sci. Lett. 2002, 21, 1885-1888. [CrossRef]

102. Mwaikambo, L.Y.; Ansell, M.P. Chemical modification of hemp, sisal, jute, and kapok fibers by alkalization. J. Appl. Polym. Sci. 2002, 84, 2222-2234. [CrossRef]

103. Corrales, F.; Vilaseca, F.; Llop, M.F.; Gironès, J.; Méndez, J.A.; Mutjé, P. Chemical modification of jute fibers for the production of green-composites. J. Hazard. Mater. 2007, 144, 730-735. [CrossRef]

104. Basak, R.; Choudhury, P.; Pandey, K.M. Impacts of Temperature Disparity on Surface Modification of Short Jute Fiber-Reinforced Epoxy Composites. IOP Conf. Ser. Mater. Sci. Eng. 2017, 225, 12114. [CrossRef]

105. Thakur, M.K.; Gupta, R.K.; Thakur, V.K. Surface modification of cellulose using silane coupling agent. Carbohydr. Polym. 2014, 111, 849-855. [CrossRef] [PubMed]

106. Gassan, J.; Bledzki, A.K. Effect of cyclic moisture absorption desorption on the mechanical properties of silanized jute-epoxy composites. Polym. Compos. 1999, 20, 604-611. [CrossRef]

107. Battegazzore, D.; Frache, A.; Carosio, F. Sustainable and High Performing Biocomposites with Chitosan/Sepiolite Layer-by-Layer Nanoengineered Interphases. ACS Sustain. Chem. Eng. 2018, 6, 9601-9605. [CrossRef]

108. Vlaev, L.; Turmanova, S.; Dimitrova, A. Kinetics and thermodynamics of water adsorption onto rice husks ash filled polypropene composites during soaking. J. Polym. Res. 2009, 16, 151-164. [CrossRef]

109. Benard, P.; Kroener, E.; Vontobel, P.; Kaestner, A.; Carminati, A. Water percolation through the root-soil interface. Adv. Water Resour. 2016, 95, 190-198. [CrossRef]

110. Wang, Y.; Wei, Q.; Wang, S.; Chai, W.; Zhang, Y. Structural and water diffusion of poly(acryl amide)/poly(vinyl alcohol) blend films: Experiment and molecular dynamics simulations. J. Mol. Graph. Model. 2017, 71, 40-49. [CrossRef]

111. Claus, H. Laccases: Structure, reactions, distribution. Micron 2004, 35, 93-96. [CrossRef]

112. Liu, R.; Dong, A.; Fan, X.; Yu, Y.; Yuan, J.; Wang, P.; Wang, Q.; Cavaco-Paulo, A. Enzymatic Hydrophobic Modification of Jute Fibers via Grafting to Reinforce Composites. Appl. Biochem. Biotechnol. 2016, 178, 1612-1629. [CrossRef] [PubMed]

113. Riva, S. Laccases: Blue enzymes for green chemistry. Trends Biotechnol. 2006, 24, 219-226. [CrossRef] [PubMed]

114. Dong, A.; Yu, Y.; Yuan, J.; Wang, Q.; Fan, X. Hydrophobic modification of jute fiber used for composite reinforcement via laccase-mediated grafting. Appl. Surf. Sci. 2014, 301, 418-427. [CrossRef]

115. Hu, R.-H.; Sun, M.-Y.; Lim, J.-K. Moisture absorption, tensile strength and microstructure evolution of short jute fiber/polylactide composite in hygrothermal environment. Mater. Des. 2010, 31, 3167-3173. [CrossRef]

116. Hong, C.K.; Kim, N.; Kang, S.L.; Nah, C.; Lee, Y.-S.; Cho, B.-H.; Ahn, J.-H. Mechanical properties of maleic anhydride treated jute fibre/polypropylene composites. Plast. Rubber Compos. 2008, 37, 325-330. [CrossRef]

117. Mouritz, A.P.; Gibson, A.G. Fire Properties of Polymer Composite Materials; Springer Science \& Business Media: Berlin, Germany, 2007.

118. Dasari, A.; Yu, Z.-Z.; Cai, G.-P.; Mai, Y.-W. Recent developments in the fire retardancy of polymeric materials. Prog. Polym. Sci. 2013, 38, 1357-1387. [CrossRef]

119. Chapple, S.; Anandjiwala, R. Flammability of Natural Fiber-reinforced Composites and Strategies for Fire Retardancy: A Review. J. Thermoplast. Compos. Mater. 2010, 23, 871-893. [CrossRef]

120. Wang, W.; Sain, M.; Cooper, P. Hygrothermal weathering of rice hull/HDPE composites under extreme climatic conditions. Polym. Degrad. Stab. 2005, 90, 540-545. [CrossRef] 
121. A Review: Natural Fiber Composites Selection in View of Mechanical, Light Weight, and Economic Properties Ahmad 2014 Macromolecular Materials and Engineering—Wiley Online Library. Available online: http://onlinelibrary.wiley.com/doi/10.1002/mame.201400089/full (accessed on 7 December 2017).

122. Hollaway, L. A review of the present and future utilisation of FRP composites in the civil infrastructure with reference to their important in-service properties. Constr. Build. Mater. 2010, 24, 2419-2445. [CrossRef]

123. Stark, N.M.; White, R.H.; Mueller, S.A.; Osswald, T.A. Evaluation of various fire-retardants for use in wood flour-polyethylene composites. Polym. Degrad. Stab. 2010, 95, 1903-1910. [CrossRef]

124. Ngo, T.D.; Ton-That, M.T.; Hu, W. Innovative and Sustainable Approaches to Enhance Fire Resistance of Cellulosic Fibers for Green Polymer Composites. SAMPE J. 2013, 49, 31-37.

125. Manfredi, L.B.; Rodriguez, E.; Wladyka-Przybylak, M.; Vazquez, A. Thermal Properties and Fire Resistance of Jute-Reinforced Composites. Compos. Interfaces 2010, 17, 663-675. [CrossRef]

126. Horrocks, A.R.; Kandola, B.K.; Kandola, B. Flammability and fire resistance of composites. In Design and Manufacture of Textile Composites; Elsevier: Amsterdam, The Netherlands, 2005; pp. 330-363.

127. Sinha, E.; Rout, S.K. Influence of fibre-surface treatment on structural, thermal and mechanical properties of jute fibre and its composite. Bull. Mater. Sci. 2009, 32, 65-76. [CrossRef]

128. Nam, T.H.; Ogihara, S.; Nakatani, H.; Kobayashi, S.; Song, J.I. Mechanical and thermal properties and water absorption of jute fiber reinforced poly(butylene succinate) biodegradable composites. Adv. Compos. Mater. 2012, 21, 241-258. [CrossRef]

129. Suppakarn, N.; Jarukumjorn, K. Mechanical properties and flammability of sisal/PP composites: Effect of flame retardant type and content. Compos. Part B Eng. 2009, 40, 613-618. [CrossRef]

130. Sain, M.; Park, S.; Suhara, F.; Law, S. Flame retardant and mechanical properties of natural fibre-PP composites containing magnesium hydroxide. Polym. Degrad. Stab. 2004, 83, 363-367. [CrossRef]

131. Morgan, A.B.; Gilman, J.W. An overview of flame retardancy of polymeric materials: Application, technology, and future directions. Fire Mater. 2013, 37, 259-279. [CrossRef]

132. Fatima, S.; Mohanty, A.; Mohanty, A. Acoustical and fire-retardant properties of jute composite materials. Appl. Acoust. 2011, 72, 108-114. [CrossRef]

133. Battegazzore, D.; Alongi, J.; Duraccio, D.; Frache, A. Reuse and Valorisation of Hemp Fibres and Rice Husk Particles for Fire Resistant Fibreboards and Particleboards. J. Polym. Environ. 2018, 26, 3731-3744. [CrossRef]

134. Matkó, S.; Toldy, A.; Keszei, S.; Anna, P.; Bertalan, G.; Marosi, G. Flame retardancy of biodegradable polymers and biocomposites. Polym. Degrad. Stab. 2005, 88, 138-145. [CrossRef]

135. Hapuarachchi, T.D.; Ren, G.; Fan, M.; Hogg, P.J.; Peijs, T. Fire Retardancy of Natural Fibre Reinforced Sheet Moulding Compound. Appl. Compos. Mater. 2007, 14, 251-264. [CrossRef]

136. Schartel, B.; Hull, T.R.; Hull, R. Development of fire-retarded materials-Interpretation of cone calorimeter data. Fire Mater. 2007, 31, 327-354. [CrossRef]

137. Bajpai, P.K.; Ahmad, F.; Chaudhary, V.; Martínez, L.M.T.; Kharissova, O.V.; Kharisov, B.I. Processing and Characterization of Bio-Composites; Springer: Berlin, Germany, 2017; pp. 1-18.

138. Biocomposites Reinforced with Natural Fibers: 2000-2010—ScienceDirect. Available online: http://www. sciencedirect.com/science/article/pii/S0079670012000391 (accessed on 18 December 2017).

139. Le Duc, A.; Vergnes, B.; Budtova, T. Polypropylene/natural fibres composites: Analysis of fibre dimensions after compounding and observations of fibre rupture by rheo-optics. Compos. Part Appl. Sci. Manuf. 2011, 42, 1727-1737. [CrossRef]

140. Bledzki, A.; Jaszkiewicz, A.; Murr, M.; Sperber, V.; Lützendgrf, R.; Reußmann, T.; Lützendorf, R. Processing techniques for natural- and wood-fibre composites. In Properties and Performance of Natural-Fibre Composites; Elsevier: Amsterdam, The Netherlands, 2008; pp. 163-192.

141. Bledzki, A.K.; Specht, K.; Cescutti, G.; Müssig, M. Comparison of different compounding processes by an analysis of fibres degradation. In Proceedings of the 3rd International Conference on Eco-Composites, Stockholm, Sweden, 20-21 June 2005; p. 3.

142. Chaitanya, S.; Singh, I. Processing of PLA/sisal fiber biocomposites using direct-and extrusion-injection molding. Mater. Manuf. Process. 2017, 32, 468-474. [CrossRef]

143. Huda, M.; Drzal, L.; Ray, D.; Mohanty, A.; Mishra, M. Natural-fiber composites in the automotive sector. In Properties and Performance of Natural-Fibre Composites; Elsevier: Amsterdam, The Netherlands, 2008; pp. 221-268. 
144. Azaman, M.; Sapuan, S.; Sulaiman, S.; Zainudin, E.; Abdan, K.; Sapuan, M.S. An investigation of the processability of natural fibre reinforced polymer composites on shallow and flat thin-walled parts by injection moulding process. Mater. Des. 2013, 50, 451-456. [CrossRef]

145. Leong, Y.; Thitithanasarn, S.; Yamada, K.; Hamada, H. Compression and injection molding techniques for natural fiber composites. In Natural Fibre Composites; Elsevier: Amsterdam, The Netherlands, 2014; pp. 216-232.

146. Thakur, V.K.; Thakur, M.K. Processing and characterization of natural cellulose fibers/thermoset polymer composites. Carbohydr. Polym. 2014, 109, 102-117. [CrossRef]

147. Stringer, L. Optimization of the wet lay-up/vacuum bag process for the fabrication of carbon fibre epoxy composites with high fibre fraction and low void content. Composites 1989, 20, 441-452. [CrossRef]

148. Yuhazri, M.; Sihombing, H. A comparison process between vacuum infusion and hand lay-up method toward kenaf/polyester composite. Int. J. Basic Appl. Sci. 2010, 10, 63-66.

149. Rouison, D.; Sain, M.; Couturier, M. Resin transfer molding of natural fiber reinforced composites: Cure simulation. Compos. Sci. Technol. 2004, 64, 629-644. [CrossRef]

150. Kang, M.K.; Lee, W.I.; Hahn, H. Formation of microvoids during resin-transfer molding process. Compos. Sci. Technol. 2000, 60, 2427-2434. [CrossRef]

151. Peng, X.; Fan, M.; Hartley, J.; Al-Zubaidy, M. Properties of natural fiber composites made by pultrusion process. J. Compos. Mater. 2012, 46, 237-246. [CrossRef]

152. Akil, H.M.; Santulli, C.; Sarasini, F.; Tirillò, J.; Valente, T. Environmental effects on the mechanical behaviour of pultruded jute/glass fibre-reinforced polyester hybrid composites. Compos. Sci. Technol. 2014, 94, 62-70. [CrossRef]

153. Almeida, J.H.S., Jr.; Amico, S.C.; Botelho, E.C.; Amado, F.D.R. Hybridization effect on the mechanical properties of curaua/glass fiber composites. Compos. Part B Eng. 2013, 55, 492-497. [CrossRef]

154. Nunna, S.; Chandra, P.R.; Shrivastava, S.; Jalan, A. A review on mechanical behavior of natural fiber based hybrid composites. J. Reinf. Plast. Compos. 2012, 31, 759-769. [CrossRef]

155. Boopalan, M.; Niranjanaa, M.; Umapathy, M. Study on the mechanical properties and thermal properties of jute and banana fiber reinforced epoxy hybrid composites. Compos. Part B Eng. 2013, 51, 54-57. [CrossRef]

156. Fiore, V.; Calabrese, L. Effect of Stacking Sequence and Sodium Bicarbonate Treatment on Quasi-Static and Dynamic Mechanical Properties of Flax/Jute Epoxy-Based Composites. Materials 2019, 12, 1363. [CrossRef]

157. Jawaid, M.; Khalil, H.A.; Abu Bakar, A.; Khanam, P.N. Chemical resistance, void content and tensile properties of oil palm/jute fibre reinforced polymer hybrid composites. Mater. Des. 2011, 32, 1014-1019. [CrossRef]

158. Jawaid, M.; Khalil, H.A.; Abu Bakar, A. Mechanical performance of oil palm empty fruit bunches/jute fibres reinforced epoxy hybrid composites. Mater. Sci. Eng. A 2010, 527, 7944-7949. [CrossRef]

159. Shanmugam, D.; Thiruchitrambalam, M. Static and dynamic mechanical properties of alkali treated unidirectional continuous Palmyra Palm Leaf Stalk Fiber/jute fiber reinforced hybrid polyester composites. Mater. Des. 2013, 50, 533-542. [CrossRef]

160. Scalici, T.; Badagliacco, D.; Enea, D.; Alaimo, G.; Valenza, A.; Fiore, V. Aging resistance of bio-epoxy jute-basalt hybrid composites as novel multilayer structures for cladding. Compos. Struct. 2017, 160, 1319-1328.

161. Shubhra, Q.T.; Alam, A.K.M.M.; Beg, M.D.H.; Khan, M.A.; Gafur, M.A. Mechanical and degradation characteristics of natural silk and synthetic phosphate glass fiber reinforced polypropylene composites. J. Compos. Mater. 2011, 45, 1305-1313. [CrossRef]

162. Yang, Y.; Ota, T.; Morii, T.; Hamada, H. Mechanical property and hydrothermal aging of injection molded jute/polypropylene composites. J. Mater. Sci. 2011, 46, 2678-2684. [CrossRef]

163. Velmurugan, R.; Manikandan, V. Mechanical properties of palmyra/glass fiber hybrid composites. Compos. Part A Appl. Sci. Manuf. 2007, 38, 2216-2226. [CrossRef]

164. Ahmed, K.S.; Vijayarangan, S.; Naidu, A. Elastic properties, notched strength and fracture criterion in untreated woven jute-glass fabric reinforced polyester hybrid composites. Mater. Des. 2007, 28, 2287-2294. [CrossRef]

165. Aquino, E.M.F.; Sarmento, L.P.S.; Oliveira, W.; Silva, R.V. Moisture Effect on Degradation of Jute/Glass Hybrid Composites. J. Reinf. Plast. Compos. 2007, 26, 219-233. [CrossRef]

166. Selver, E.; Ucar, N.; Gulmez, T. Effect of stacking sequence on tensile, flexural and thermomechanical properties of hybrid flax/glass and jute/glass thermoset composites. J. Ind. Text. 2018, 48, 494-520. [CrossRef] 
167. Manikandan, N.; Morshed, M.N.; Karthik, R.; Al Azad, S.; Deb, H.; Rumi, T.M.; Ahmed, M.R. Improvement of mechanical properties of natural fiber reinforced jute/polyester epoxy composite through meticulous alkali treatment. Am. J. Curr. Org. Chem. 2017, 3, 9-18.

168. Ku, H.; Wang, H.; Pattarachaiyakoop, N.; Trada, M. A review on the tensile properties of natural fiber reinforced polymer composites. Compos. Part B Eng. 2011, 42, 856-873. [CrossRef]

169. Shalwan, A.; Yousif, B.; Yousif, B. In State of Art: Mechanical and tribological behaviour of polymeric composites based on natural fibres. Mater. Des. 2013, 48, 14-24. [CrossRef]

170. Faruk, O. Cars from Jute and Other Bio-Fibers, 2009. Available online: http://docplayer.net/48269780-Carsfrom-jute-and-other-bio-fibers.html. (accessed on 28 December 2018).

171. Karus, M.; Kaup, M.; Lohmeyer, D. Study on markets and prices for natural fibres (Germany and EU). In Proceedings of the 3rd International Symposium Bioresource Hemp, Wolfsburg, Germany, 13-16 September 2000.

172. Netravali, A.N.; Chabba, S. Composites get greener. Mater. Today 2003, 6, 22-29. [CrossRef]

(C) 2019 by the authors. Licensee MDPI, Basel, Switzerland. This article is an open access article distributed under the terms and conditions of the Creative Commons Attribution (CC BY) license (http://creativecommons.org/licenses/by/4.0/). 